\title{
Vasculature Guides Migrating Neuronal Precursors in the Adult Mammalian Forebrain via Brain-Derived Neurotrophic Factor Signaling
}

\author{
Marina Snapyan, ${ }^{1 *}$ Morgane Lemasson, ${ }^{1 \star}$ Monika S. Brill, ${ }^{3,4}$ Mathieu Blais, ${ }^{5}$ Mireille Massouh, ${ }^{1,2}$ Jovica Ninkovic, ${ }^{3,4}$ \\ Claude Gravel, ${ }^{2,6}$ François Berthod, ${ }^{5}$ Magdalena Götz, ${ }^{3,4}$ Philip A. Barker, ${ }^{7}$ André Parent, ${ }^{2}$ and Armen Saghatelyan ${ }^{1,6}$ \\ ${ }^{1}$ The Cellular Neurobiology Unit and ${ }^{2}$ The Systemic Neurobiology Unit, Centre de Recherche Université Laval Robert-Giffard, Québec, Québec, Canada G1J \\ 2G3, ${ }^{3}$ Department of Physiological Genomics, Institute of Physiology and Center for Integrated Protein Science Munich, Ludwig Maximilian University \\ Munich, D-80336 Munich, Germany, ${ }^{4}$ Institute for Stem Cell Research, Helmholtz Zentrum München-National Research Center for Environmental Health, \\ D-85764 Neuherberg/Munich, Germany, ${ }^{5}$ Laboratoire d’Organogénèse Expérimentale, Centre Hospitalier Affilié Universitaire de Québec, Département de \\ Chirurgie, Université Laval, Hôpital du Saint-Sacrement, Québec, Canada G1S 4L8, ํDepartement of Psychiatry, Université Laval, Québec, Québec, Canada \\ G1K 7P4, and 7Montreal Neurological Institute, McGill University, Montreal, Québec, Canada H3A 2B4
}

Adult neuronal precursors retain the remarkable capacity to migrate long distances from the posterior (subventricular zone) to the most anterior [olfactory bulb $(\mathrm{OB})$ ] parts of the brain. The knowledge about the mechanisms that keep neuronal precursors in the migratory stream and organize this long-distance migration is incomplete. Here we show that blood vessels precisely outline the migratory stream for new neurons in the adult mammalian forebrain. Real-time video imaging of cell migration in the acute slices demonstrate that neuronal precursors are retained in the migratory stream and guided into the $\mathrm{OB}$ by blood vessels that serve as a physical substrate for migrating neuroblasts. Our data suggest that endothelial cells of blood vessels synthesize brain-derived neurotrophic factor (BDNF) that fosters neuronal migration via p75NTR expressed on neuroblasts. Interestingly, GABA released from neuroblasts induces $\mathrm{Ca}^{2+}{ }_{-}$ dependent insertion of high-affinity TrkB receptors on the plasma membrane of astrocytes that trap extracellular BDNF. We hypothesize that this renders BDNF unavailable for p75NTR-expressing migrating cells and leads to their entrance into the stationary period. Our findings provide new insights into the functional organization of substrates that facilitate the long-distance journey of adult neuronal precursors.

\section{Introduction}

Since the discovery of neuronal progenitors in the adult brain approximately four decades ago (Altman and Das, 1966; Hinds, 1968), a key question in the field has been how these neuronal precursors migrate long distances, through complex brain territories, from the posterior to the most anterior parts of the brain. Neuronal precursors are generated in the subventricular zone (SVZ) and migrate first tangentially, in chains, along the rostral migratory stream (RMS) and, once in the olfactory bulb (OB), turn to migrate radially and individually out of the RMS into the

\footnotetext{
Received 0ct. 14, 2008; revised Feb. 5, 2009; accepted Feb. 6, 2009.

This work was supported by Canada Foundation for Innovation (CFI), Parkinson Society Canada, and Canadian Institutes of Health Research (CIHR) grants (A.S.). A.S. is a recipient of a Canada Research Chair in postnatal neurogenesis. We thank Drs. S. Nakamura (National Institute of Neuroscience, Tokyo, Japan), E. Castren (University of Helsinki, Helsinki, Finland) for providing BDNF plasmids, Dr. M. Kojima (National Institute of Advanced Science and Technology, Ikeda, Japan) for providing BDNF-GFP plasmid, Dr. J. Lee (Harvard Gene Therapy Initiative, Harvard Medical School, Boston, MA) for providing defective retroviral vector pMMP-f2-IRES-EGFP, and Drs. Freda Miller, Alain Trembleau, and Isabelle Caille for the comments on a previous version of this manuscript.

${ }^{*}$ M.S. and M.L. contributed equally to this work.

Correspondence should be addressed to Armen Saghatelyan, Centre de Recherche Université Laval RobertGiffard, Université Laval, 2601 Chemin de la Canardiere, Quebec, Quebec, Canada G1J 2G3. E-mail: armen.saghatelyan@crulrg.ulaval.ca.

DOI:10.1523/JNEUROSCI.4956-08.2009

Copyright $\odot 2009$ Society for Neuroscience $\quad$ 0270-6474/09/294172-17\$15.00/0
}

bulbar layer (Alvarez-Buylla and Garcia-Verdugo, 2002; Lledo and Saghatelyan, 2005).

Molecular signals that are involved in tangential migration of neuroblasts in the adult brain include the following: polysialated neural cell adhesion molecule (PSA-NCAM) (Cremer et al., 1994; Ono et al., 1994; Hu et al., 1996); members of the Slit (Wu et al., 1999); ephrin-B (Conover et al., 2000) and integrin families (Murase and Horwitz, 2002; Belvindrah et al., 2007); astrocytederived factor of unknown identity (Mason et al., 2001); the ErbB4 (Anton et al., 2004) and prokineticin 2 (Ng et al., 2005) receptors and neuroblast-derived GABA (Bolteus and Bordey, 2004). Reelin and tenascin-R, two extracellular matrix molecules, contribute to radial migration of neuronal precursors (Hack et al., 2002; Saghatelyan et al., 2004). Despite the extensive investigation of the molecular signals involved in the neuronal migration in the adult brain, our knowledge of how the RMS is defined and how neuronal precursors find their routes toward and into OB remains incomplete.

The most widely accepted model accounting for neuronal precursor migration posits that cell movements are dictated by chemorepulsive and chemoattractive gradients. Thus, neuroblasts are forced to remain in the migratory stream as a result of the action of chemorepellent molecules secreted from neighboring 
territories, such as Slit released from the septum (Wu et al., 1999) and choroid plexus (Sawamoto et al., 2006), and are guided by chemoattractive molecules secreted from the $\mathrm{OB}$ that include prokineticin 2 (Ng et al., 2005) and glial cell line-derived neurotrophic factor (Paratcha et al., 2006). However, surgical removal of the OB does not abolish neuronal migration (Jankovski et al., 1998; Kirschenbaum et al., 1999), suggesting that molecules secreted from the $\mathrm{OB}$ are not essential for neuroblasts migration in the adult RMS (Marín and Rubenstein, 2003). Furthermore, the migratory pathway of newborn cells in the adult brain has very complex curvature architecture and numerous chemorepellent molecule gradients acting in concert and with different efficiency would be required to ensure a faithful migration.

In the studies presented here, we have tested the hypothesis that neuroblasts migrate along physical substrates that topographically define the RMS. We show that blood vessels precisely outline the migratory stream for new neurons from the posterior (SVZ) to the most anterior (OB) regions of the adult brain and that they serve as a physical substrate for migrating neuroblasts in the adult brains. We identify brain-derived neurotrophic factor (BDNF) as a molecular signal that is released from endothelial cells of blood vessels and show that it fosters neuronal migration via p75NTR activation on neuroblasts. Interestingly, GABA released from neuroblasts leads to the insertion of high-affinity TrkB receptors on the plasma membrane of astrocytes that ensheath neuronal precursors and contact blood vessels. Consequently, astrocytes trap free extracellular BDNF. We hypothesize that, via this mechanism, neuroblasts control the amount of extracellular BDNF and, therefore, the periodicity of the migratory periods. Together, our data provide functional and mechanistic explanations for long-distance journey of new cells in the adult brain. This information may contribute to the development of new strategies to cure neurodegenerative diseases and brain trauma.

\section{Materials and Methods}

Animals. All experiments were performed in adult 2- to 3-month-old C57BL/J6 mice (Charles River), GAD67-green fluorescent protein (GFP)-deficient mice (Ono et al., 2005), and p75NTR-deficient mice (Lee et al., 1992) in accordance with Laval Institute guidelines. TrkB floxed mice (Minichiello et al., 1999) were crossed with GlastCre::ERT2 mice (Mori et al., 2006), which carry an inducible form of Cre in the astrocyte-specific glutamate transporter (GLAST) locus. As experimental animals, TrkB ${ }^{\mathrm{f} / \mathrm{fl}}$ GLAST::CreERT2 and control TrkB ${ }^{\text {wildtype/wildtype }}$ GLAST::CreERT2 were used. Two- to 3-month-old mice received intraperitoneal injections of $1 \mathrm{mg}$ of Tamoxifen, two injections per day for 5 consecutive days (Mori et al., 2006). To evaluate the proportion of cells that underwent recombination, GLAST::CreERT2 mice were crossed with reporter mice (Z/EG). Animals were kept on a $12 \mathrm{~h}$ light/dark cycle at constant temperature $\left(22^{\circ} \mathrm{C}\right)$ with food and water ad libitum.

Stereotaxic injections and osmotic minipump infusions. To label newborn neurons, GFP-encoding retrovirus was injected either to the SVZ (for analysis of cell migration in the RMS) or to the RMS (for analysis of cell migration in the $\mathrm{OB}$ ) at the following coordinates (in $\mathrm{mm}$ ): for the SVZ, anteroposterior, 0.75 ; mediolateral, 1.20; dorsoventral, 1.9; and for the RMS, anteroposterior, 2.55; mediolateral, 0.82; dorsoventral, 2.9. BDNF (100 ng; Peprotech) and vehicle $(\mathrm{NaCl}, 0.9 \%)$ were injected stereotaxically to the striatum at the following coordinates (in $\mathrm{mm}$ ): anteroposterior, 0.9 ; mediolateral, 0.8 ; dorsoventral, 2.1. IgG-Fc, TrkB-Fc (10 $\mu \mathrm{g} / \mathrm{ml} ; 100 \mu \mathrm{l}$ infusion volume; R \& D Systems), and function-blocking antibodies for p75NTR described previously (Clary and Reichardt, 1994) were infused via $7 \mathrm{~d}$ osmotic minipumps (Alzet) at the following coordinates (in $\mathrm{mm}$ ): anteroposterior, 2.55; mediolateral, 0.82; dorsoventral, 2.7. Double-stranded siSTABLE small interfering RNAs (siRNA) directed against BDNF mRNA were obtained from Dharmacon. In addi- tion, FITC fluorescent tag was added to $5^{\prime}$ end of siRNA. The sense and antisense sequences of BDNF were designed as follows: sense, GAACTACCCAATCGTATGTTTT; antisense, ACATACGATTGGGTAGTTCTT. BDNF siRNA and control siRNA were infused via $7 \mathrm{~d}$ osmotic minipump directly to the external carotid artery. For this, mouse jugular catheter (Alzet) connected to the osmotic minipump was inserted to the external carotid artery and maintained in place with non-absorbable silk sutures. Heparin at $5 \mu \mathrm{l}$ was added to $100 \mu \mathrm{l}$ of solution containing either control or BDNF siRNAs.

Immunohistochemistry and in situ hybridization. Immunohistochemistry was performed as described previously (Saghatelyan et al., 2004). The following antibodies were used: rabbit (N-20; 1:50; Santa Cruz Biotechnology), goat (K-14; 1:50; Santa Cruz Biotechnology), and chicken (1:50; Promega) anti-human BDNF; goat anti-human (N-20; 1:50; Santa Cruz Biotechnology) and rabbit anti-mouse (1:1000; Millipore Bioscience Research Reagents) TrkB; rabbit anti-human (H-137; 1:50; Santa Cruz Biotechnology) and anti-rat (1:500; Covance and 1:500; Millipore) p75NTR; guinea-pig anti-mouse doublecortin (1:1000; Abcam); mouse anti-PSA-NCAM (1:1000; Millipore Bioscience Research Reagents); mouse anti-5-bromo-2'-deoxyuridine (BrdU) (1:200; Serotec); rabbit (1:1000; Dako) and mouse (1:1000; Millipore Bioscience Research Reagents) anti-GFAP; rabbit anti-caspase 3 (1:500; Cell Signaling Technology); and rabbit anti-Ki67 (1:1000; Abcam) and rat anti-mouse platelet/ endothelial cell adhesion molecule (PECAM) (1:1000; BD Pharmingen). For some immonstainings, we used tyramide amplification kit (PerkinElmer Life and Analytical Sciences). The DNA synthesis marker $\mathrm{BrdU}$ (Sigma) was dissolved in a sterile solution of $0.9 \% \mathrm{NaCl}$ and $1.75 \%$ $\mathrm{NaOH}(0.4 \mathrm{~N})$. This solution was injected intraperitoneally at a concentration of $50 \mathrm{mg} / \mathrm{kg}$ body weight. Two injections of BrdU spaced $2 \mathrm{~h}$ apart were performed $5 \mathrm{~d}$ before killing the animals to evaluate the number of $\mathrm{BrdU}$-positive $\left(\mathrm{BrdU}^{+}\right)$in the $\mathrm{RMS}_{\mathrm{OB}}$. For osmotic minipump infusion of IgG-Fc, TrkB-Fc, and function-blocking antibodies for p75NTR above the horizontal limb of RMS, BrdU was injected twice spaced by $2 \mathrm{~h}$ $2 \mathrm{~d}$ before installation of pumps. One pulse of $\mathrm{BrdU}$ was given $6 \mathrm{~h}$ before installation of pumps to the carotid artery. BrdU staining was performed as described previously (Saghatelyan et al., 2004), and BrdU ${ }^{+}$cells were counted in each third $40-\mu \mathrm{m}$-thick section. In some experiments, blood vessels were visualized by injecting fluorescent dextran (molecular weight, $70,000 \mathrm{kDa}$ ) to the tail vein. Corresponding secondary antibodies were used. Images were acquired with an FV1000 confocal microscope equipped with argon $488 \mathrm{~nm}$, helium-neon $543 \mathrm{~nm}$, and helium-neon $633 \mathrm{mn}$ lasers (Olympus). Double- and triple-immunolabeled cells were analyzed using three-dimensional (3D) reconstructed images with the $x-z$ and $y-z$ orthogonal projections.

For in situ hybridization studies, antisense RNA probes were labeled using the DIG RNA labeling kit (Roche Diagnostics) and purified on ProbeQuant G-50 columns (GE Healthcare). In situ hybridization was performed on $50-\mu \mathrm{m}$-thick vibratome sections, and the signals were revealed with nitroblue-tetrazolium-chloride/5-bromo-4-chlor-indolylphosphate (Promega). Antisense RNA probes were obtained from plasmids containing a fragment of the extracellular domain of mouse TrkB (kindly provided by Dr. Lino Tessarollo, National Institutes of Health, Bethesda, MD) and two plasmids containing mouse BDNF [kindly provided by Drs. S. Nakamura (National Institute of Neuroscience, Tokyo, Japan) and E. Castren (University of Helsinki, Finland)].

Retrovirus production. The replication defective retroviral vector pMMP-f2-IRES-EGFP (obtained from Dr. J. Lee, Harvard Gene Therapy Initiative, Harvard Medical School, Boston, MA) was produced by calcium phosphate-mediated transfection of the vector DNA into the retrovirus-packaging cell line GPG-293 and was subsequently concentrated from the supernatant by ultracentrifugation. Titration was performed by infecting NIH-3T3 cells with serial dilutions of the vector and counting the number of enhanced GFP (EGFP)-positive cells or colonies $72 \mathrm{~h}$ after infection.

Slice preparation and time-lapse video imaging. Sagittal sections (250 $\mu \mathrm{m})$ from adult (2-3 months old) mouse forebrain were prepared and maintained at $32^{\circ} \mathrm{C}$. Slices were continually superfused $(2 \mathrm{ml} / \mathrm{min})$ with artificial CSF (ACSF) containing the following (in mM): $125 \mathrm{NaCl}, 26$ $\mathrm{NaHCO}_{3}, 10$ glucose, $3 \mathrm{KCl}, 2 \mathrm{CaCl}_{2}, 1.3 \mathrm{MgCl}_{2}$, and $1.25 \mathrm{NaH}_{2} \mathrm{PO}_{4}$ 
(bubbled with $95 \% \mathrm{O}_{2} / 5 \% \mathrm{CO}_{2}$ ), $\mathrm{pH} \sim 7.4$. For $\mathrm{Ca}^{2+}$ imaging of astrocytes, slices were incubated for $1 \mathrm{~h}$ with $2 \mu \mathrm{M}$ Fluo4-AM, a membranepermeable $\mathrm{Ca}^{2+}$ indicator. For time-lapse video imaging of cell migration and $\mathrm{Ca}^{2+}$ fluctuation in astrocytes, multiple $z$-stack images (at least $6-10 z$-sections, with $\sim 10 \mu \mathrm{m}$ interval) were acquired every $15 \mathrm{~s}$ for at least $1 \mathrm{~h}$ with a BX61WI (Olympus) upright microscope equipped with CCD camera (CoolSnap HQ2). For $\mathrm{Ca}^{2+}$ imaging experiments, Fluo4 was excited by using a DG-4 xenon light source (Sutter Instruments). At least 20 migrating cells were analyzed per slice and for each time point. Multiple $z$-step acquisition in our time-lapse experiments of cell migration allowed us to follow the same cell in different $z$ plans. For the analysis of stationary periods, we took into consideration only those phases that were intercepted by two migratory periods. For the experiments requiring pharmacological treatment (BDNF, antibodies, GABA, bicuculline, etc.), time-lapse movies were first acquired under control conditions for $30-45 \mathrm{~min}$ and then in the presence of the pharmacological agent for another 30-45 min. Under these conditions, we were unable to see long stationary phases (intercepted by two migratory periods), and, therefore, our values for stationary periods are shorter compared with the ones obtained from $1.5-2 \mathrm{~h}$ of recordings (see Fig. $2 F$ ). At least 50 time points were averaged for each slice to obtain the mean value for the changes induced by pharmacological agent. Control values were calculated by averaging 50 time points before drug application. These values were than averaged across all slices. Because of low amounts of p75NTR functionblocking antibodies, we incubated the slices with these antibodies for $1 \mathrm{~h}$ before recording. For time-lapse video imaging of $\mathrm{GFP}^{+}$neuroblasts along dextran-Texas Red-labeled blood vessels, imaging was performed deep in the slice (40-100 $\mu \mathrm{m}$ from the slice surface).

Fluorescence-activated cell sorting and neurosphere analysis. SVZ was dissected from five animals, and tissue was dissociated to the single cells. Single-cell suspension was incubated with rabbit anti-rat p75NTR (1: 200; Millipore) on ice for $20 \mathrm{~min}$ and then washed with PBS containing $1 \%$ fetal calf serum (FCS). Anti-p75NTR binding was detected with Alexa 647-coupled anti-rabbit IgG (1:500; Invitrogen). Before sorting, cells were washed with PBS containing $0.5 \mu \mathrm{g} / \mathrm{ml}$ propidium iodide to exclude dead cells. Cells were sorted on a FACSAria (BD Biosciences) and collected into the medium containing epidermal growth factor (EGF) and basic fibroblast growth factor (FGF). Sorted cells were plated into 96-well tissue culture plates at density of one cell per well, as confirmed by counting $4 \mathrm{~h}$ after plating, in FGF $(10 \mathrm{ng} / \mathrm{ml})$ and EGF $(20 \mathrm{ng} / \mathrm{ml})$ containing medium. After $7 \mathrm{~d}$ of culturing, neurosphere formation was used as a readout for proliferative activity of p75-positive and p75-negative cell populations. The identity of the sorted cells was assessed immediately after the sorting. Namely, 1000 fluorescence-activated cell sorting (FACS) events have been cytospined, cells were fixed in 4\% paraformaldehyde and stained for doublecortin (Dcx) (rabbit antibody; 1:200; Millipore) and GFAP (rabbit antibody; 1:200; Dako) visualized by the secondary anti-rabbit antibodies coupled with cyanine 2 and 3 , respectively.

Reverse transcription-PCR analysis of FACS-purified cell populations. SVZ was dissected from five hGFAP-EGFP transgenic mice per experiment, and tissue was dissociated to the single cells. The following cell populations were purified using FACS: astrocytes (GFP-positive, PSANCAM-negative population), neuroblasts (PSA-NCAM-positive population, mouse IgM, 1:100), and endothelial cells (vascular endothelial cadherin-positive cells, mouse IgG, 1:400) as described above. Immediately after the sorting, the total RNA was isolated from the different populations using RNeasy Micro kit (Qiagen), according to the instructions of the manufacturer. First-strand cDNA synthesis reaction was performed with RevertAid H Minus First Strand cDNA Synthesis kit (Fermentas Life Science) with oligo-dT primers. Obtained cDNA were amplified using the following primers: for BDNF, 5'-CAACATAAATCCACTATCTTC-3' and 5' -ATGACCATCCTTTTCCTTAC-3'; for TrkB, 5' -TGAAGACGCTGAAGGACGCCA- $3^{\prime}$ and 5'-CAGGTTCTCTCCTACCAAGCA-3'; for p75NTR, 5'-CCAGCAGACCCACACACAGACTG-3' and 5'-CCCTACACAGAGATGCTCGGTTC-3'; for glyceraldehyde-3-phosphate dehydrogenase, 5' -TCCCATTCTTCCACCTTTGATG- $3^{\prime}$ and $5^{\prime}$-GTCCACCACCCTGTTGCTGTA-3'; and for $\beta$-actin, $5^{\prime}$-CACCACTTTCTACAATGAGC- $3^{\prime}$ and $5^{\prime}$-CGGTCAGGATCTTCATGAGG-3'.
Primary culture of adult astrocytes. To prepare culture of astrocytes from the adult SVZ, the lateral wall of the lateral ventricle from the brains of at least five 6- to 9-week-old C57BL/J6 mice were dissected out under a microscope. Preparation was performed in HBSS containing $10 \mathrm{~mm}$ HEPES. The isolated brain tissue was then centrifuged and resuspended in $10 \mathrm{ml}$ of culture medium. Cells were cultured under adherent conditions in the presence of $10 \%$ fetal bovine serum, $5 \%$ horse serum, DMEM/F-12 supplemented with B27 and growth factors (20 ng/ml EGF and $10 \mathrm{ng} / \mathrm{ml} \mathrm{FGF2).} \mathrm{Medium} \mathrm{was} \mathrm{changed} \mathrm{every} \mathrm{second} \mathrm{day.} \mathrm{For} \mathrm{ELISA}$ experiments, astrocytes were seeded on poly-D-lysine-coated coverslips in six-well plates. For coculture of astrocytes and endothelial cells, astrocytes were prepared as described, and then human umbilical vein endothelial cells (HUVECs) transfected with BDNF-GFP plasmid (kindly provided by Dr. M. Kojima, National Institute of Advanced Science and Technology, Ikeda, Japan) were added. The cocultures were analyzed $24 \mathrm{~h}$ later with the help of FV1000 confocal microscope (Olympus). After control acquisition of $\mathrm{GFP}^{+}$punctate labeling on the surface of astrocytes, a small region of interest was selected and bleached for $1 \mathrm{~min}$ with an argon $488 \mathrm{~nm}$ laser. Astrocytes were visualized in bright-field images according to their large soma size and were identified with post hoc staining with GFAP antibodies.

Isolation of fibroblasts and endothelial cells. Human fibroblasts were isolated from skin biopsies after breast reductive surgeries as described previously (Berthod et al., 2006) using $0.2 \mathrm{IU} / \mathrm{ml}$ collagenase $\mathrm{H}$ (Roche Diagnostics). Cells were grown in DMEM (Invitrogen) supplemented with $10 \%$ FCS (HyClone), $100 \mathrm{IU} / \mathrm{ml}$ penicillin G (Sigma), and $25 \mathrm{mg} / \mathrm{ml}$ gentamicin (Schering) and incubated in $8 \% \mathrm{CO}_{2}$ at $37^{\circ} \mathrm{C}$. HUVECs were obtained from healthy newborns by enzymatic digestion with 0.250 $\mathrm{mg} / \mathrm{ml}$ thermolysin (Sigma) as described previously (Berthod et al., 2006). They were grown in endothelial growth medium-2 (EGM-2; Cambrex Bioscience Baltimore) and characterized as described previously (Berthod et al., 2006).

Construction of the tissue-engineered $3 D$ capillary-like network. Collagen-chitosan sponges were used as a scaffold to construct a $3 \mathrm{D}$ capillary-like network as described previously (Berthod et al., 2006). Briefly, type I and III bovine collagen (Symatese) and chitosan (Kemestrie) were dissolved and mixed in $0.1 \%$ acetic acid, and $1 \mathrm{ml} /$ well $(3.8$ $\mathrm{cm}^{2}$ ) of the final solution was poured in 12-well plates (BD Biosciences), frozen at $-80^{\circ} \mathrm{C}$, and lyophilized in a vacuum lyophilizer (Dura-Stop Freeze-Dryer; FTS Systems). Human dermal fibroblasts and HUVECs $\left(2.1 \times 10^{5} \mathrm{cells} / \mathrm{cm}^{2}\right.$ each $)$ were seeded on top of the sponges and cultured for $10 \mathrm{~d}$ in a 1:1 ratio of EGM-2/DMEM, supplemented with 75 $\mu \mathrm{g} / \mathrm{ml}$ ascorbic acid. The sponges were cultured in a 3:1 ratio of DMEM/ Ham's F-12 medium supplemented with $10 \%$ FBS, $0.4 \mu \mathrm{g} / \mathrm{ml}$ hydrocortisone, $5 \mu \mathrm{g} / \mathrm{ml}$ bovine insulin, $100 \mu \mathrm{g} / \mathrm{ml}$ ascorbic acid, and antibiotics and were elevated to the air-liquid interface for 17 additional days.

For time-lapse imaging of migrating neuroblasts in the reconstituted 3D capillary-like network, GFP ${ }^{+}$cells derived from the SVZ of GAD67GFP mice were cultured together with HUVECs and fibroblast prepared sponges. In control experiments, $\mathrm{GFP}^{+}$neuroblasts were cultured with sponges prepared from fibroblasts alone. HUVECs were transduced with GFP lentivirus. $\mathrm{GFP}^{+}$neuroblasts (small cells of $\sim 5-10 \mu \mathrm{m}$ size) and $\mathrm{GFP}^{+}$capillaries (long tubular-like structures) were easily distinguishable on the basis of their shapes and were false-colored in offline analysis using ImagePro software (see Fig. $6 L$ ).

For reconstituted capillaries, siRNA transfection were performed with HiPerFect transfection reagent (Qiagen) according to the instructions of the manufacturer. BDNF and control siRNAs were provided from Santa Cruz Biotechnology (sc-42121 and sc-37007, respectively). BDNF siRNA were a pool of three target-specific 20-25 nt siRNA designed to knock down BDNF gene expression. Control siRNA were a nontargeting siRNA designed as negative control. Each transfection was effectuated with 70 $\mu \mathrm{M}$ of siRNA. Total RNA was prepared using the Invitrogen TRIzol reagent according to the instructions of the manufacturer. siRNA efficiency were checked by reverse transcription (RT)-PCR reaction with the primers provided from Santa Cruz Biotechnology (sc-42121-Pr).

Determination of BDNF concentration. The primary culture of astrocytes from adult SVZ were treated with GABA $(10 \mu \mathrm{M})$ for $30 \mathrm{~min}$. The total protein concentration was determined by Bradford assay (Bio- 

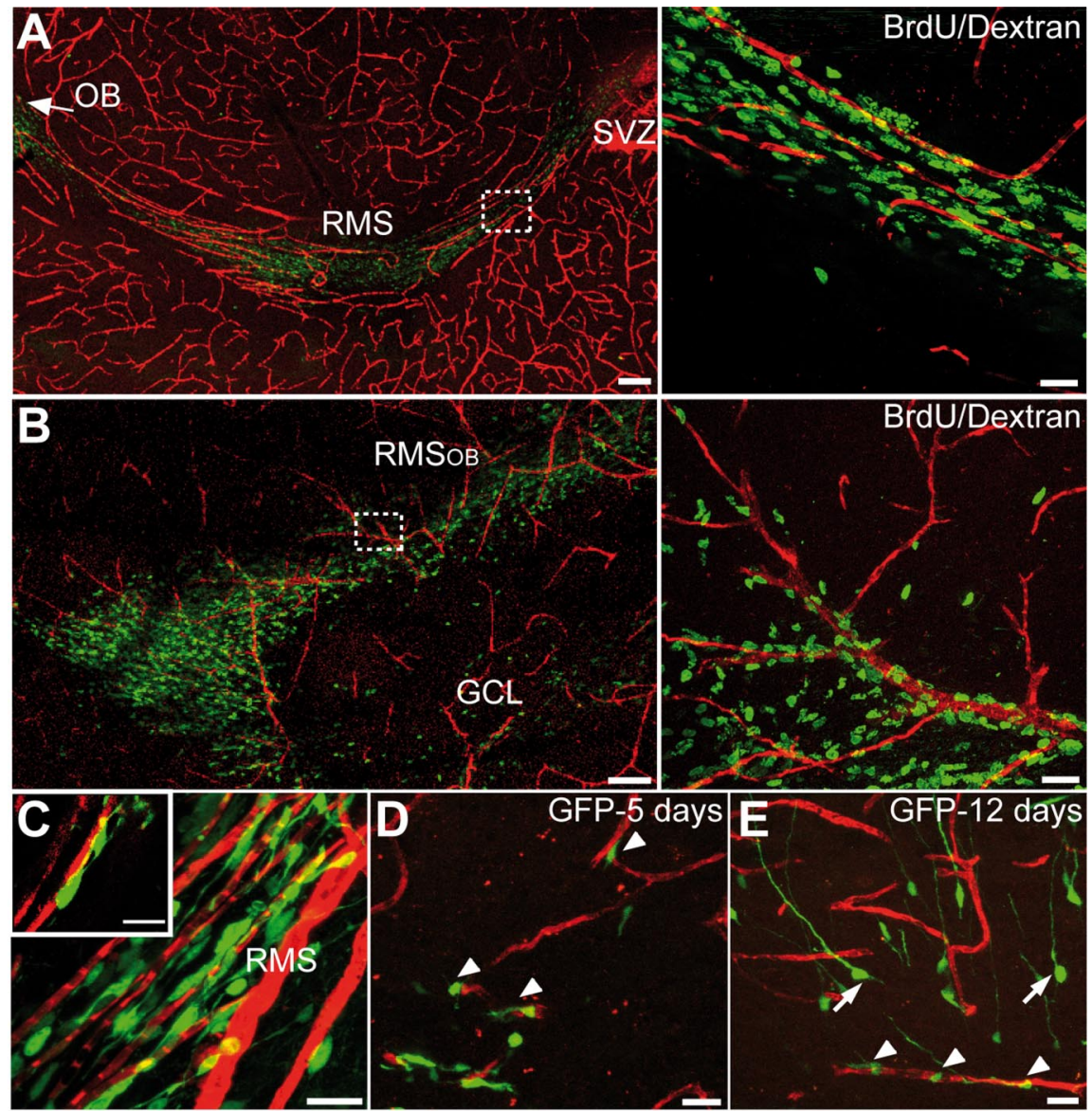

\section{$\mathbf{F}$}

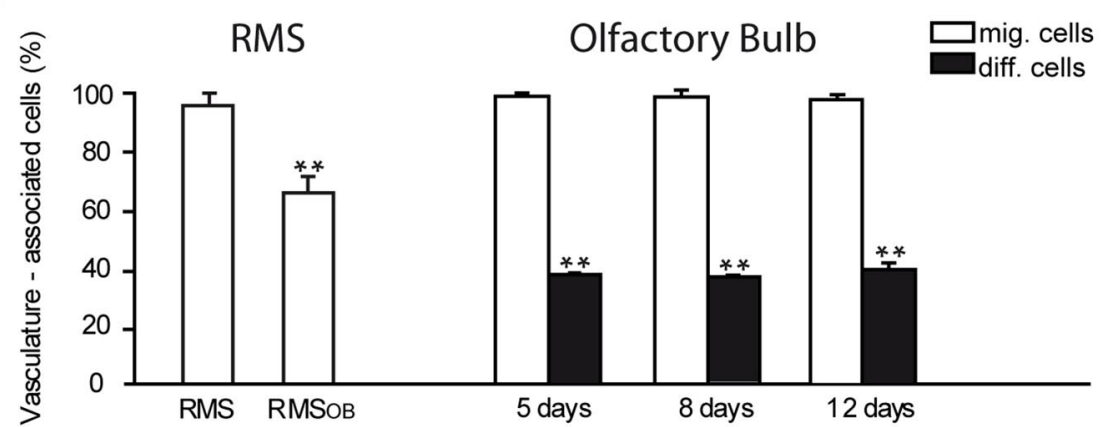

Figure 1. Migrating neuroblasts are aligned along the blood vessels in the adult brain. $A, B$, Micrographs showing organization of blood vessels in the adult mouse forebrain. Note the close association of tangentially $(\boldsymbol{A})$ and radially $(\boldsymbol{B})$ migrating neurona precursors (green) with blood vessels (red) that parallel the migratory stream. Newly generated cells in the migratory pathway were labeled by BrdU injection $5 \mathrm{~d}$ before analysis. Blood vessels were revealed by injection of dextran-Texas Red to the tail vein Scale bars: $\boldsymbol{A}, \boldsymbol{B}, 100 \mu \mathrm{m} ; \boldsymbol{A}_{\text {right }}{ }^{\prime} \boldsymbol{B}_{\text {right }}, 20 \mu \mathrm{m}$. $\boldsymbol{C}-\boldsymbol{E}$, Vasculature-associated GFP ${ }^{+}$cells in the RMS and OB. GFP-expressing retrovirus was injected into the SVZ $(\boldsymbol{C})$ or RMS $(\boldsymbol{D}, \boldsymbol{E}) 5,8$, and $12 \mathrm{~d}$ before analysis. Arrowheads and arrows indicate migrating (mig.) and differentiating (diff.) cells, respectively. Scale bars, $10 \mu \mathrm{m}$. $\boldsymbol{F}$, Quantification of vasculature-associated cells in the RMS and $O B$.

Rad), and BDNF concentration was measured by BDNF $\mathrm{E}_{\max }$ ImmunoAssay system (Promega) according to the protocol of the manufacturer. Exogenous BDNF (10 ng/ml) was added to the cultures for $30 \mathrm{~min}$, and then cultures were washed extensively and treated with GABA as described.

Surface TrkB internalization. TrkB internalization was evaluated by biotinylation of surface $\operatorname{TrkB}$ receptors. Acute slices of the adult mouse forebrain were incubated in bicuculline $(100 \mu \mathrm{M}), \mathrm{GABA}(10 \mu \mathrm{M})$, or BDNF (10 $\mathrm{ng} / \mathrm{ml}$ ) for $1 \mathrm{~h}$. After incubation, slices were immediately transferred to icecold HBSS, and the RMS and SVZ were extracted under a dissecting microscope. The cells were dissociated, washed in ice-cold PBS, and biotinylated with EZ-Link Sulfo-NHS-biotin (Pierce) for 30 min according to the protocol of the manufacturer. The cells were then extensively washed with ice-cold PBS containing $100 \mathrm{~mm}$ glycine and lysed using a buffer containing the following (in $\mathrm{mM}$ ): 50 Tris- $\mathrm{HCl}, 1$ EDTA, 1 EGTA, 1 sodium orthovanadate, 50 sodium fluoride, 5 sodium pyrophosphate, 10 sodium b-glycerophosphate, $0.1 \%$ 2-mercaptoethanol, 1\% Triton X-100, and a 1:100 dilution of freshly added protease inhibitor cocktail set III (Calbiochem). The biotinylated surface proteins were immobilized on streptavidincoated agarose beads (GE Healthcare), incubated with anti-TrkB antibodies, followed by incubation with HRP-labeled secondary antibodies. HRP-labeled TrkB immunocomplexes were eluted in $0.1 \mathrm{M}$ glycine- $\mathrm{HCl}$, and surface TrkB protein concentrations were determined by ELISA.

Statistical analysis. Data are presented as mean \pm SEM. Statistical significance was tested by using Student's $t$ test (with ${ }^{\star} p<0.05$ and ${ }^{\star *} p<0.001$ )

\section{Results}

Adult neuronal precursors are aligned and migrate along the blood vessels To investigate whether the SVZ-OB pathway contains physical substrates that might be used by neuronal precursors for their faithful migration from the posterior to the most anterior parts of the brain, we performed blood vessel labeling in the adult mammalian forebrain. When blood vessels were labeled via injection of fluorescent dextran-Texas Red into the tail vein or by immunohistochemical detection for PECAM, a marker of endothelial cells, an unexpected organization of blood vessels was observed in the SVZ-OB pathway. Blood vessels in most parts of the brain are distributed in a rather random manner, but, in the RMS, they parallel the migratory stream and almost all migrating cells are aligned along the blood vessels (Fig. 1A) (supplemental Video 1, available at www.jneurosci.org as supplemental material). Interestingly, blood vessel organization is modified in the core of the $\mathrm{OB}$, in which neuroblasts have to detach from each other and start to migrate radially. Whereas some blood vessels are still oriented parallel to the migratory stream and reach the most rostral end of the RMS of $\mathrm{OB}\left(\mathrm{RMS}_{\mathrm{OB}}\right)$, many others are organized perpendicular with respect to the tangentially migrating neuroblasts (Fig. $1 B$ ). Moreover, cells that exit from the $\mathrm{RMS}_{\mathrm{OB}}$ and initiate their radial migration into the bulbar layers do so along these perpendicularly oriented blood vessels (Fig. $1 B$ ). Quantification of the number of BrdU-labeled migrating cells (to reveal migrating cells, BrdU was injected $5 \mathrm{~d}$ before counting) along the blood vessels revealed that, among $444 \mathrm{BrdU}$-labeled cells, $75.3 \pm 4.1 \%$ of them were within $3 \mu \mathrm{m}$ of blood vessels ( $n=3$ animals). Because BrdU labeling depicts only cell nuclei and not the cell body or processes, these numbers likely underrepresent the proportion of 


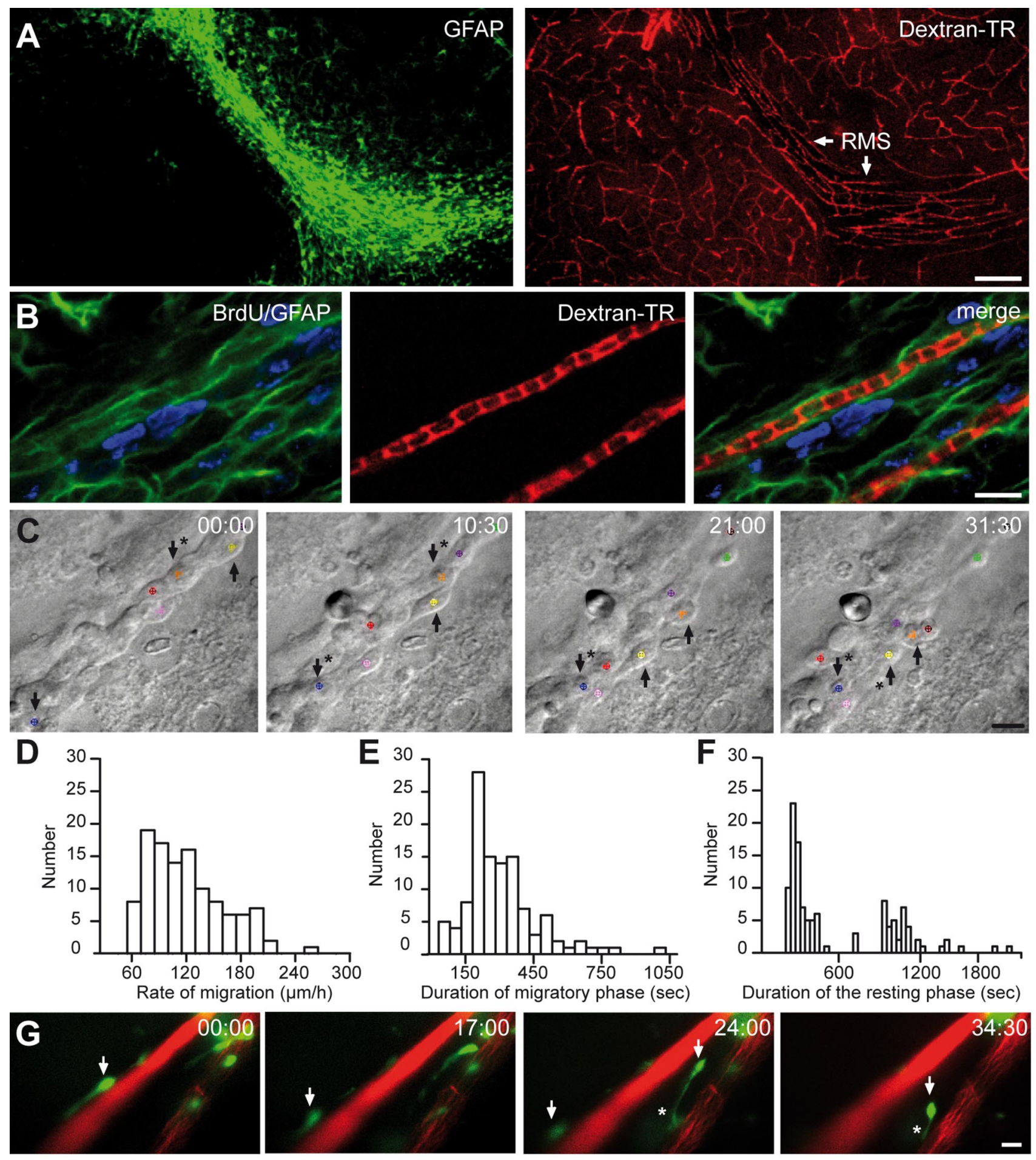

$H$ repellent/attraction-guided migration model

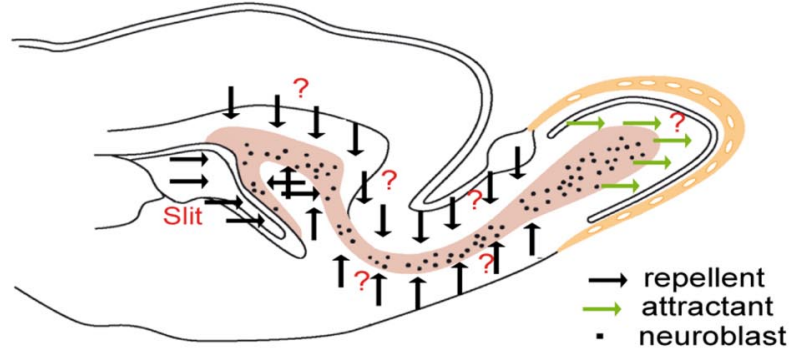

vasculature-guided migration model

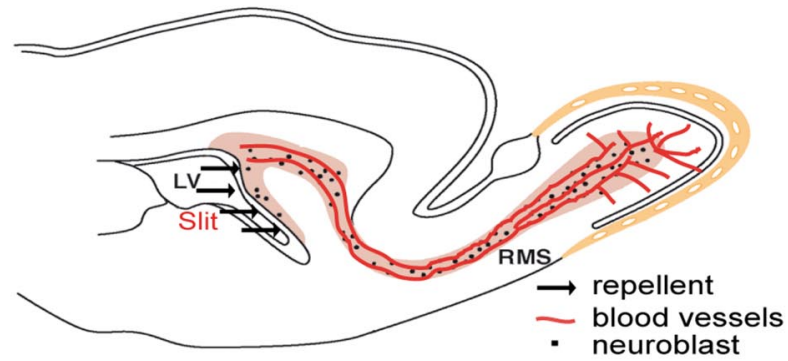


blood vessel-associated neuroblasts. Therefore, we counted the number of vasculature-associated neuroblasts whose soma or leading process could be easily identified in either GAD67-GFP transgenic animals or animals in which a GFP-encoding retrovirus was injected into the SVZ. Among $921 \mathrm{GFP}^{+}$cells counted in the RMS, $97.3 \pm 0.7 \%$ of neuroblasts were located within $3 \mu \mathrm{m}$ of blood vessels ( $n=5$ animals) (Fig. $1 C, F$ ). This number is decreased in the $\mathrm{RMS}_{\mathrm{OB}}$ in which neuroblasts have to change their mode of migration from tangential to radial. At this level, $33.3 \pm$ $4.9 \%$ of $\mathrm{GFP}^{+}$neuroblasts were "detached" from blood vessels (Fig. $1 F$; see also B). However, only vasculature-associated neuronal-specific nuclear protein-negative migrating cells are found in the $\mathrm{OB}$ at 5,8 , and $12 \mathrm{~d}$ after stereotaxic RMS injection of GFP-encoding retrovirus $(99.4 \pm 1.2 \%, n=161$ cells from 4 animals, at $5 \mathrm{~d} ; 98.9 \pm 2.0 \%, n=91$ cells from 5 animals, at $8 \mathrm{~d}$; and $98.3 \pm 1.7 \%, n=93$ cells from 4 animals, at $12 \mathrm{~d}$ ) (Fig. $1 D-F)$. After their arrival to the $\mathrm{OB}$, newborn cells that start to differentiate and develop long dendritic processes $(>30 \mu \mathrm{m})$ were equally abundant close to or distant from blood vessels (Fig. $1 E, F)$.

To determine whether migrating cells physically contact blood vessels, we performed coimmunostains for BrdU-labeled neuroblasts, for vasculature, and for astrocytes (Fig. 2A,B), which are known to ensheath migrating cells (Alvarez-Buylla and Garcia-Verdugo, 2002; Lledo and Saghatelyan, 2005). Analysis of sections after triple immunolabeling revealed that blood vessels are enveloped by the processes of GFAP-expressing astrocytes and that BrdU- or Dcx-labeled migrating cells are attached to these processes (Fig. $2 \mathrm{~B}$ ). These data revealed that adult neuroblasts, enveloped by astrocytic processes, are positioned close $(<3 \mu \mathrm{m}$ away) to blood vessels, but they do not show whether these migrating cells use blood vessels as a scaffold for their migration. To investigate this issue, we decided to monitor migrat-

\section{$\leftarrow$}

Figure 2. Neuronal precursors migrate along the blood vessels in the adult brain. $\boldsymbol{A}, \mathrm{GFAP}$ labeled astrocytes (green) and dextran-Texas Red (TR)-labeled blood vessels (red) in the adult RMS. Note the parallel organization of blood vessels in the RMS. Scale bar, $100 \mu \mathrm{m}$. B, Micrographs of BrdU-positive cells ( $5 \mathrm{~d}$ after BrdU injection) in the close vicinity of dextran-Texas Red-loaded blood vessels (injection to the tail vein). GFAP-labeled astrocytes (green) envelop blood vessels (red), and neuroblasts (blue) are attached to the astrocytic processes. Scale bar, 10 $\mu \mathrm{m}$. C, Time-lapse video imaging of migrating neuroblasts in slices from the adult mouse forebrain (time is indicated in minutes in the top right corner of each photograph). Migrating cells are indicated during their migratory (arrows only) and stationary (arrows with asterisks) phases. $\boldsymbol{D}-\boldsymbol{F}$, Rate of migration and durations of migratory and stationary periods of neuronal precursors in the RMS in the acute slices of mouse forebrain. G, GFP-labeled neuronal precursors migrate along blood vessels in the acute slices of the adult mouse forebrain. Blood vessels were labeled by injection of dextran-Texas Red to the tail vein $1 \mathrm{~h}$ before preparation of acute slices. GFP-expressing retrovirus was injected into the SVZ $3 \mathrm{~d}$ before time-lapse imaging in the RMS. Arrows indicate the soma of migratory cells, whereas asterisk shows leading process. Note that $\mathrm{GFP}^{+}$cells are always positioned close to the vasculature either with their soma or leading processes. Time is indicated in minutes in the top right corner of each photograph. Scale bar, 10 $\mu \mathrm{m} . \boldsymbol{H}$, Schematic representation of the adult brain showing the migratory pathway. According to the repellent/attraction-guided model, neuroblasts remain in this complex-shaped migratory stream because of myriads of chemorepellent molecules (black arrows) secreted from all RMS-neighboring territories and are guided toward $O B$ attributable to chemoattractive molecules secreted from the this region (green arrows). According to the vasculature-guided migration model proposed herein, neuroblasts are retained in the RMS and migrate in this pathway as a result of the presence of blood vessels that are oriented parallel to the migratory stream. Neuroblasts course along blood vessels, and a single chemorepellent molecule that is secreted from the posterior parts of the brain could be sufficient to direct neuronal precursors to the $O B$. Neuroblasts receive all other signal(s) for their migration from RMS-OB vasculature. It should be noted, however, that the vasculature-guided migration model proposed here does not exclude the earlier chemorepellent/chemoattraction-mediated scheme. It is likely that both mechanisms operate in parallel to ensure faithful migration of newborn cells in the adult brain. ing neuroblasts in real time. For this, we studied the behavior of migrating neuronal precursors in acute slices of the adult (2-3 months old) mouse forebrain with time-lapse video imaging. This analysis revealed fast migration of neuronal precursors in the RMS (121.2 $\pm 3.9 \mu \mathrm{m} / \mathrm{h} ; n=64$ cells from 4 animals) (Fig. $2 C, D$ ) (supplemental Video 2, available at www.jneurosci.org as supplemental material). The migration of neuronal precursors was saltatory and comprised two distinct phases: displacement of neuronal cell body toward the leading process $(288.1 \pm 18.4 \mathrm{~s}$; $n=64$ cells from 4 animals) (Fig. $2 E$ ) separated by a resting period ( $492.3 \pm 41.5 \mathrm{~s} ; n=64$ cells from 4 animals) (Fig. 2 F). To examine whether these migrating neuroblasts used blood vessels for their saltatory displacement, we imaged GFP-labeled neuronal precursors deep in the slices in which dextran-Texas Redstained blood vessels preserve their integrity. Our time-lapse analysis revealed that $88.1 \pm 4.6 \%$ of neuronal precursors migrate along blood vessels $(<3 \mu \mathrm{m}$ away during entire period of recording) in the adult RMS ( $n=118$ cells from 7 animals) (Fig. 2G) (supplemental Video 3, available at www.jneurosci.org as supplemental material). Even in the cases when the soma of $\mathrm{GFP}^{+}$neuroblasts migrate $>3 \mu \mathrm{m}$ away from the blood vessels, these cells almost invariably preserve their leading process close to blood vessels (Fig. 2G) (supplemental Videos 3,4, available at www.jneurosci.org as supplemental material). This type of migration is likely to be used under circumstances when migrating neuronal precursors meet some physical constrains (such as soma of astrocytes or neuroblasts in the stationary phase) that impede straightforward propagation along the blood vessel. Together, these data indicate that vasculature plays an important role in the migratory behavior of neuronal precursors in the RM$\mathrm{S}-\mathrm{OB}$ pathway and that these migratory cells use blood vessels for their navigation in the adult brain (for a model, see Fig. $2 \mathrm{H}$ ). But what are the mechanisms of this vasculature-associated migration?

\section{Mechanisms of vasculature-associated migration}

Endothelial cells synthesize BDNF (Leventhal et al., 1999; Louissaint et al., 2002; Guo et al., 2008), injection of this trophic factor into the lateral ventricle leads to the appearance of new neurons in the parenchyma of the striatum (Benraiss et al., 2001; Pencea et al., 2001; Bédard and Parent, 2004) (but see also (Galvão et al., 2008), and it has been suggested recently that BDNF affects migration of neuronal precursors in the RMS (Chiaramello et al., 2007; Bath et al., 2008). We therefore tested the putative role of BDNF in the vasculature-guided migration of neuronal precursors. In situ hybridization analysis for BDNF combined with immunohistochemistry for PECAM showed BDNF mRNA expression in the endothelial cells of blood vessels in the adult RMS (Fig. $3 A$ ). In contrast, astrocytes and neuroblasts in the RMS were devoid of BDNF mRNA (Fig. 3A) (supplemental Fig. 1, available at www.jneurosci.org as supplemental material). Semiquantitative RT-PCR analysis of FACS-purified endothelial cells, astrocytes, and neuroblasts confirmed the presence of BDNF mRNA in the endothelial cells but not in other cells types of the adult migratory pathway ( $n=3$ experiments) (Fig. $3 B$ ). Interestingly, however, immunodetection of BDNF revealed a different distribution with the protein mostly found on the astrocytic processes enveloping blood vessels (Fig. $3 C$ ). To confirm that our immunostaining reflects the actual presence of BDNF protein, immunostains were also performed on sections derived from TrkB-Fcinfused animals. Application of TrkB-Fc $(10 \mu \mathrm{g} / \mathrm{ml})$ via $7 \mathrm{~d}$ osmotic minipump implants placed just above the horizontal limb of the RMS, to capture endogenous BDNF, decreased the 


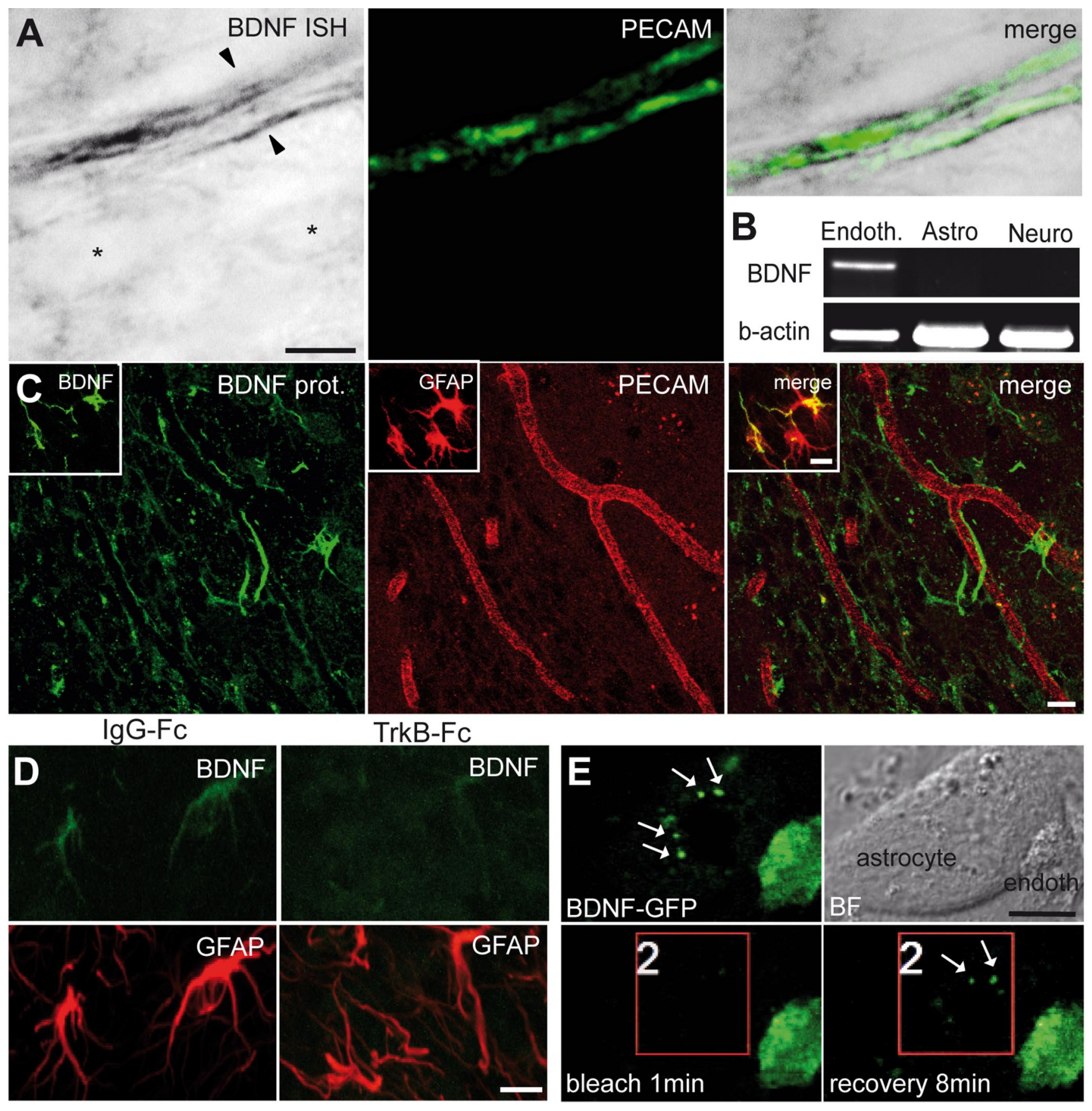

Figure 3. Expression of BDNF in the adult RMS. $A$, In situ hybridization (ISH) for BDNF and immunostaining for PECAM (green) showing that endothelial cells of blood vessels synthesize BDNF. Note that BDNF mRNA is present in the endothelial cells (arrowheads) but not in other cell types of the adult RMS (asterisks). Scale bar, $5 \mu \mathrm{m}$. $\boldsymbol{B}$, RT-PCR analysis of FACS-purified endothelial cells (Endoth.), astrocytes (Astro), and neuroblasts (Neuro). BDNF is expressed in endothelial cells but not in astrocytes and neuroblasts. C, Immunostaining for BDNF in the adult mouse RMS. Inset shows colocalization of BDNF (green) and GFAP (red). Scale bar, $10 \mu \mathrm{m}$. D, Immunostaining for BDNF (green) and GFAP (red) in the adult mouse RMS after osmotic minipump infusion of TrkB-Fc or IgG-Fc, as a control. BDNF immunostaining is drastically reduced after $7 \mathrm{~d}$ of TrkB-Fc infusion. Scale bar, $10 \mu \mathrm{m}$. E, Coculture of astrocytes with BDNF-GFP-transfected endothelial cells. Note the strong GFP signal in the endothelial cells and punctate staining (arrows) of astrocyte. Bright-field (BF) images are also shown. Bleaching area is indicated by the red square. After 8 min of recovery period, the punctate staining reappears at the surface of astrocyte. Scale bar, $10 \mu \mathrm{m}$.

intensity of immunostaining for this trophic factor on astrocytes ( $n=4$ animals) (Fig. $3 D$ ). In addition, coculturing of SVZ astrocytes with BDNF-GFP-transfected endothelial cells revealed punctate staining for GFP on the surface of these glial cells (Fig. $3 E)$. This punctate labeling reappears several minutes after bleaching of GFP on the astrocytes ( $n=10$ cells from 3 independent experiments) (Fig. $3 E$ ). No such staining was observed in control experiments when astrocytes were cocultures with only
GFP-transfected endothelial cells (data not shown). These data suggest that BDNF is synthesized by the endothelial cells, secreted into the extracellular space, and bound to receptors on astrocytic processes. Importantly, the pattern of BDNF expression was not observed outside of the RMS, in which neuroblast migration ends (granule cell layer of the OB) or is not observed (striatum) (supplemental Figs. 1, 2, available at www.jneurosci.org as supplemental material). Astrocytes were devoid of BDNF immunoreac- 


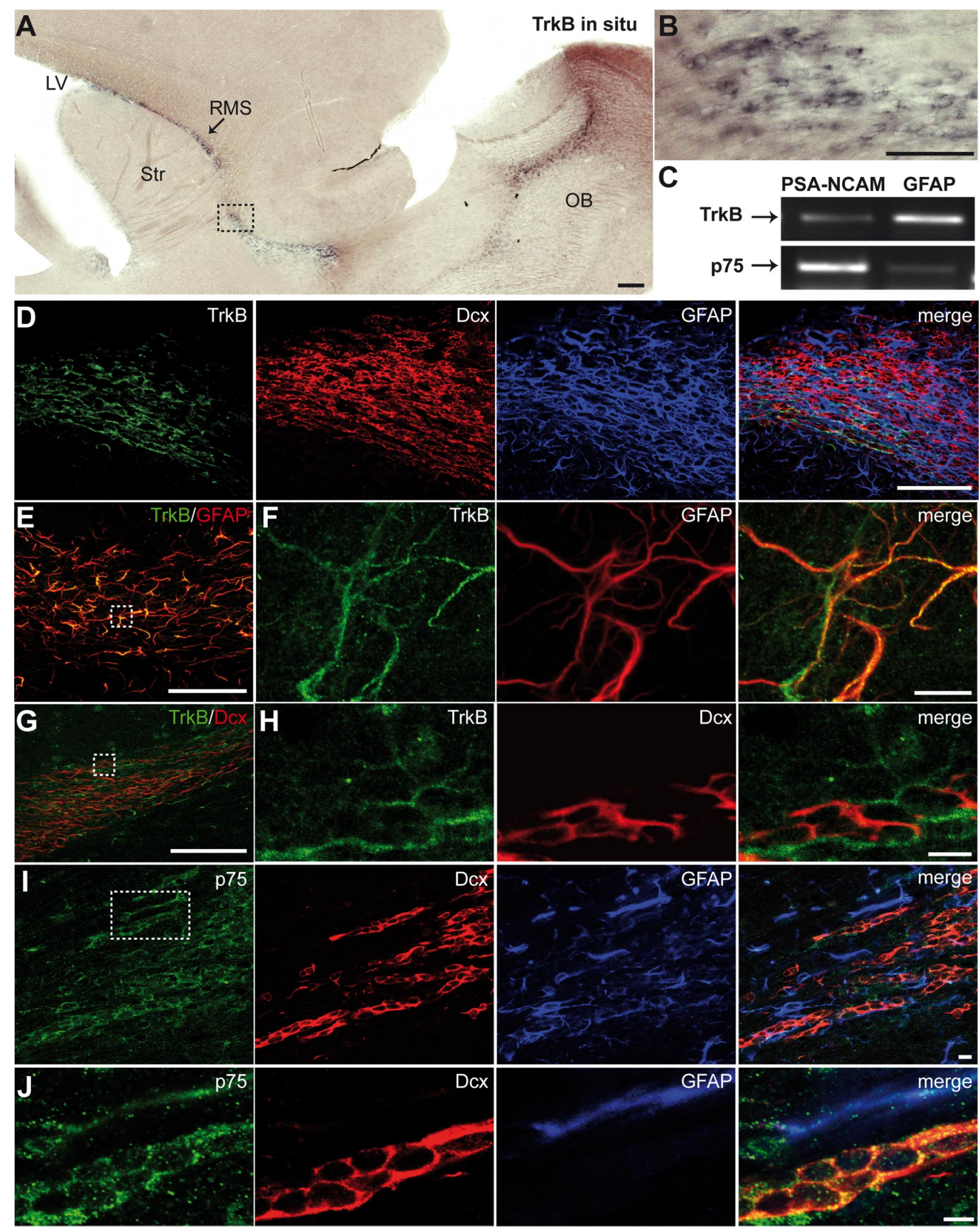

Figure 4. Expression of TrkB and p75NTR in the adult RMS. A, In situ hybridization for TrkB in the adult SVZ-OB pathway. Note the intense labeling in the adult RMS. Scale bar, $100 \mu \mathrm{m}$. LV, Lateral ventricle; Str, striatum. $\boldsymbol{B}$, High-magnification images of the boxed areas in $\boldsymbol{A}$. Scale bar, $10 \mu \mathrm{m}$. C, RT-PCR analysis of FACS-purified astrocytes (GFAP) and neuroblasts (PSA-NCAM). Note the high level of expression of p75NTR in neuroblasts and TrkB receptors in astrocytes. $\boldsymbol{D}$, Immunostaining for TrkB (green), Dcx (red), and GFAP (blue) in the adult mouse RMS. Scale bar, $100 \mu \mathrm{m}$. $\boldsymbol{E}, \boldsymbol{F}$, Immunostaining for TrkB (green) and GFAP(red) in the adult mouse RMS.F, High-magnification images of the boxed area in $\boldsymbol{E}$. Scale bars: $\boldsymbol{E}, 100 \mu \mathrm{m} ; \boldsymbol{F}, 10 \mu \mathrm{m}$. $\boldsymbol{G}, \boldsymbol{H}$, Micrographs showing that most, if not all, of TrkB (green) immunopositivity is not localized in Dcx-immunopositive cells (red). $\boldsymbol{H}$, High-magnification images of the boxed area in $\mathbf{G}$. Scale bars: $\mathbf{G}, 100 \mu \mathrm{m} ; \boldsymbol{H}, 10 \mu \mathrm{m}$. $\boldsymbol{I}, \boldsymbol{J}$, Micrographs displaying expression of p75NTR (green) by migrating neuroblasts (Dcx, red). J, High-magnification images of the boxed area in (I). Scale bar, $10 \mu \mathrm{m}$. 


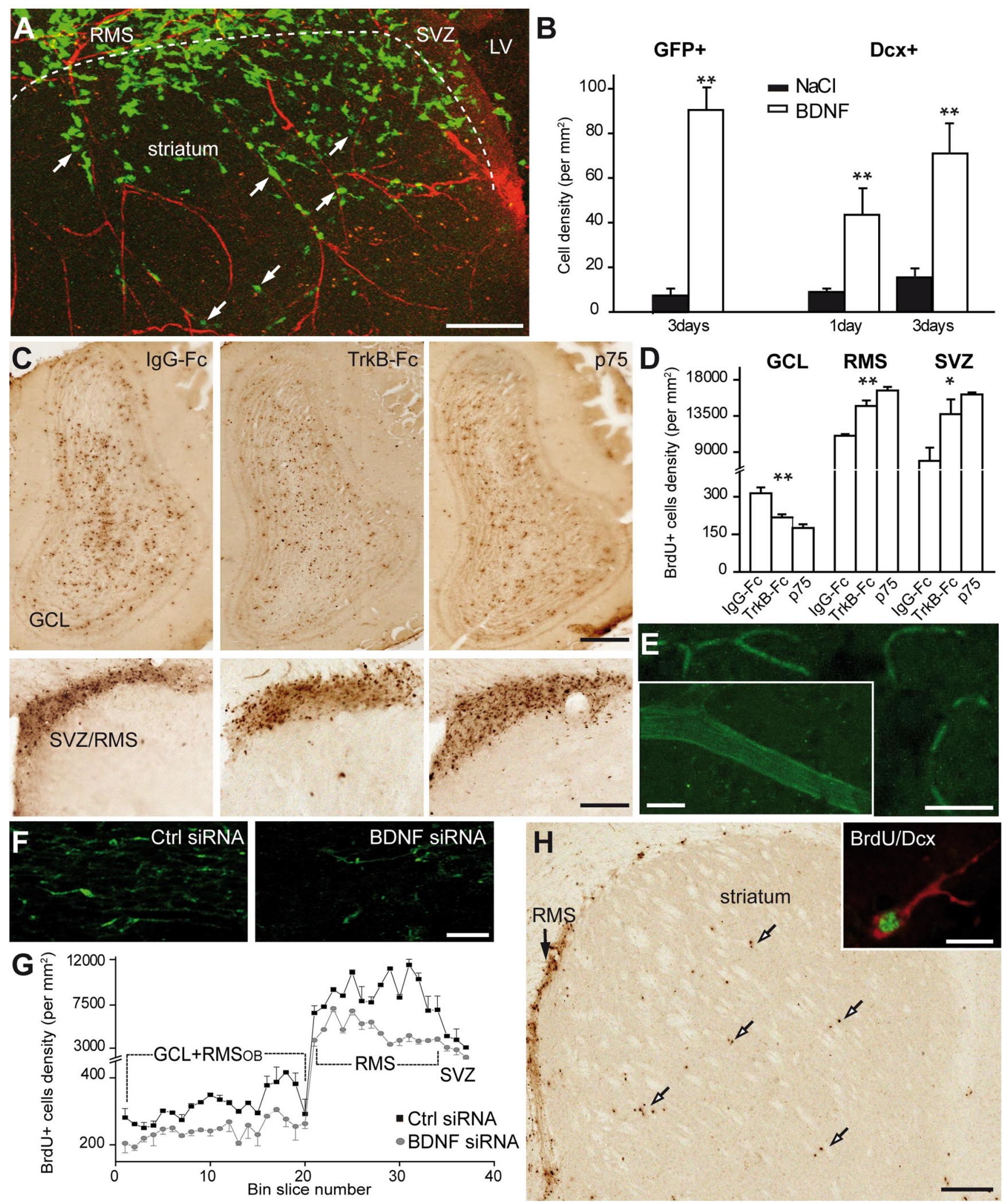

Figure 5. BDNF induces vasculature-associated cell migration in the adult forebrain. $A$, Micrographs illustrating migration of GFP ${ }^{+}$neuroblasts into the striatum $3 \mathrm{~d}$ after stereotaxic injection of BDNF (100 ng) to this region. GFP-expressing retrovirus was injected into the SVZ $2 \mathrm{~d}$ before injection of BDNF. Note that numerous migrating neuroblasts (arrows) use blood vessels for their navigation into the striatum. LV, Lateral ventricle. Scale bar, $100 \mu \mathrm{m}$. B, Quantification of the density of GFP ${ }^{+}$and Dcx ${ }^{+}$derouted cells in the striatum. C, Micrographs showing BrdU ${ }^{+}$cells in the OB and SVZ/RMS $7 \mathrm{~d}$ after osmotic minipump infusions of $\mathrm{lgG}-\mathrm{Fc}(10-90 \mu \mathrm{g} / \mathrm{ml}), \operatorname{TrkB}-\mathrm{Fc}(10 \mu \mathrm{g} / \mathrm{ml})$, and p75NTR function-blocking antibodies ( $90 \mu \mathrm{g} / \mathrm{ml})$ just above horizontal limb of the RMS. BrdU was injected $2 \mathrm{~d}$ before osmotic minipump installation. Note the reduced number of BrdU ${ }^{+}$cells in the OB and increased number in the SVZ/RMS of TrkB-Fc and p75NTR function-blocking antibody infused animals. Scale bar, $100 \mu \mathrm{m}$. D, Density of BrdU ${ }^{+}$cells in the granule cell layer (GCL) of the OB, RMS, and SVZ of lgG-Fc, TrkB-Fc, and p75NTR function-blocking antibody infused animals. $E$, Labeling of blood vessels after osmotic minipump infusion of fluorescently tagged BDNF siRNA to the carotid artery. Control and BDNF siRNAs were infused for $7 \mathrm{~d}$. Inset shows high-magnification image of fluorescently tagged siRNA-labeled blood vessel. Scale bars: $E, 50 \mu \mathrm{m}$; inset, $10 \mu \mathrm{m}$. $\boldsymbol{F}$, Immunostaining for BDNF in the control and BDNF (Figure legend continues.) 
tivity in these regions (supplemental Fig. 2, available at www.jneurosci.org as supplemental material).

We next performed immunostaining, in situ hybridization, and semiquantitative RT-PCR on FACS-purified neuroblasts and on astrocytes to determine which cell types in the adult RMS expressed the neurotrophin receptors TrkB and p75NTR. TrkB was found mostly on astrocytes (Fig. $4 A-H$ ), whereas p75NTR was expressed mainly by migrating neuroblasts (Fig. $4 C, I, J$ ) and by a small fraction of GFAP-immunopositive cells (Fig. $4 J$ ). In the adult SVZ, p75NTR immunoreactivity was also observed in C-type cells (Young et al., 2007). Evaluation of FACS-purified $\mathrm{p} 75 \mathrm{NTR}^{+}$population of cells in the SVZ revealed that $20.2 \pm$ $1.3 \%$ of cells were neurosphere-forming cells ( $n=3$ independent sorting experiments), as reported previously (Young et al., 2007). However, already in the SVZ, $\sim 38$ and $7 \%$ of FACS-isolated p75NTR ${ }^{+}$cells were $\mathrm{Dcx}^{+}$and $\mathrm{GFAP}^{+}$, respectively $(n=3$ independent sorting experiments). These data indicate that p75NTR starts to be expressed by some migrating neuroblasts in the SVZ. We were not able to detect C-type cells expressing p75NTR immunoreactivity in the RMS, in contrast to what was reported recently (Bath et al., 2008). It has been shown previously that this population of cells is virtually absent in the adult RMS (Jankovski and Sotelo, 1996; Lois et al., 1996; Doetsch et al., 1997; Gritti et al., 2002).

\section{BDNF fosters neuronal migration via $\mathrm{p} 75 \mathrm{NTR}$}

The expression patterns of BDNF and its receptors suggest that this trophic factor might be involved in the vasculatureassociated migration of neuronal precursors. To investigate the role of BDNF in the neuronal migration in adult brain, we delivered this trophic factor into the striatum, a brain region that borders the migrating stream but in which neuronal precursors do not normally migrate. Three days after stereotaxic injection of BDNF (100 ng) in the striatum, numerous $\mathrm{GFP}^{+}$neuronal precursors (stereotaxically labeled in the SVZ with a retroviral vector encoding GFP $2 \mathrm{~d}$ before application of BDNF) were derouted from their normal migratory pathway toward the BDNF-injected zone, whereas few were derouted after a control saline injection $\left(8.2 \pm 1.4 \mathrm{cells} / \mathrm{mm}^{2}\right.$ in control vs $90.1 \pm 12.4 \mathrm{cells} / \mathrm{mm}^{2}$ in BDNF-injected mice; $n=3$ animals; $p<0.001$ ) (Fig. 5A,B). Remarkably, $75.0 \pm 3.6$ of these derouted cells still migrated along blood vessels ( $n=3$ animals) (Fig. $5 A$ ). Similarly, the density of $\mathrm{Dcx}^{+}$precursors was increased in the striatum 1 and $3 \mathrm{~d}$ after BDNF injection $\left(9.4 \pm 1.1\right.$ cells $/ \mathrm{mm}^{2}$ in control vs $43.5 \pm 16.0$ cells $/ \mathrm{mm}^{2}$ in $1 \mathrm{~d}$ BDNF-injected mice, $n=3$ animals, $p<0.001$; and $12.6 \pm 4.1$ cells $/ \mathrm{mm}^{2}$ in control vs $71.2 \pm 13.0$ cells $/ \mathrm{mm}^{2}$ in $3 \mathrm{~d}$ BDNF-injected mice, $p<0.001 ; n=3$ animals per group) (Fig. $5 B$ ) (supplemental Fig. 3, available at www.jneurosci.org as supplemental material). To remove endogenous BDNF from the RMS, we implanted osmotic minipumps containing either TrkB-Fc or IgG-Fc $(10 \mu \mathrm{g} / \mathrm{ml})$ just above the horizontal limb of the RMS. After $7 \mathrm{~d}$ treatment, $\mathrm{BrdU}^{+}$cells, with BrdU being injected $2 \mathrm{~d}$ before installation of pumps, were sharply reduced in the OB of TrkB-Fc-treated

\section{$\leftarrow$}

(Figure legend continued.) siRNAs-treated animals. Note the reduced intensity of immunostaining. Scale bar, $20 \mu \mathrm{m}$. G, Density of BrdU ${ }^{+}$cells in the SVZ-OB pathway after control (black squares) and BDNF (gray squares) siRNA infusion to the carotid artery. Single pulse of BrdU was given $6 \mathrm{~h}$ before installation of osmotic minipumps. BrdU ${ }^{+}$cells were counted in the coronal sections spaced by $120 \mu \mathrm{m}$ throughout the SVZ-OB pathway. $\boldsymbol{H}$, Micrographs displaying $\mathrm{BrdU}^{+}$cells in the RMS of BDNF siRNA-treated animals. Note that numerous BrdU ${ }^{+}$cells (arrows) leave RMS and migrate to the striatum. Inset shows high-magnification image of BrdU (green) and Dcx (red) colabeled cell in the striatum. Scale bars: $\boldsymbol{H}, 100 \mu \mathrm{m}$; inset, $10 \mu \mathrm{m}$. animals $\left(313.5 \pm 23.3\right.$ cells $/ \mathrm{mm}^{2}$ in IgG-FC vs $216.8 \pm 13.1$ cells/ $\mathrm{mm}^{2}$ in TrkB-Fc-infused mice; $n=4$ animals; $p<0.001$ ) (Fig. $5 C, D)$. Interestingly, this reduction in the $\mathrm{OB}$ was accompanied by concomitant increase in $\mathrm{BrdU}^{+}$cells in the RMS and SVZ $\left(11,021.5 \pm 221.4\right.$ cells $/ \mathrm{mm}^{2}$ in IgG-FC vs $14,733.0 \pm 698.7$ cells/ $\mathrm{mm}^{2}$ in TrkB-Fc-infused mice for the RMS, $p<0.001$; and $8212.0 \pm 1631.7$ cells $/ \mathrm{mm}^{2}$ in IgG-FC vs $13,736.2 \pm 1836.8$ cells/ $\mathrm{mm}^{2}$ in TrkB-Fc-infused mice for the SVZ, $n=4$ animals, $p<0.05$ ) (Fig. $5 C, D$ ). Similar results were obtained when the Dcx immunofluorescence intensity was analyzed in the OB of TrkB-Fc-infused animals (supplemental Fig. 3, available at www.jneurosci.org as supplemental material). Cell survival in the RMS was not affected by TrkB-Fc infusion (supplemental Fig. 3, available at www. jneurosci.org as supplemental material). Thus, our in vivo gain-offunction and loss-of-function experiments demonstrates that BDNF plays a crucial role in neuronal migration in the adult brain and are compatible with recent observations of decreased number of $\mathrm{BrdU}^{+}$ cells in the OB of BDNF haploinsufficient mice $28 \mathrm{~d}$ after BrdU injection (Bath et al., 2008).

Because migrating neuroblasts express p75NTR, we investigated whether this receptor is involved in BDNF-induced migration. For this, we implanted osmotic minipumps containing either function-blocking antibodies for p75NTR (Clary and Reichardt, 1994) or IgG-Fc (90 $\mu \mathrm{g} / \mathrm{ml})$ just above the horizontal limb of the RMS. This treatment reduced the number of $\mathrm{Dcx}^{+}$ (supplemental Fig. 3, available at www.jneurosci.org as supplemental material) and $\mathrm{BrdU}^{+}$cells in the $\mathrm{OB}(313.5 \pm 23.3$ cells/ $\mathrm{mm}^{2}$ in IgG-FC vs $175.0 \pm 14.7 \mathrm{cells} / \mathrm{mm}^{2}$ in p75NTRantibody-infused mice; $n=3$ animals; $p<0.001$ ) (Fig. 5C,D) and increased their number in the RMS and SVZ $(11,021.5 \pm 221.4$ cells $/ \mathrm{mm}^{2}$ in IgG-FC vs $16,920.0 \pm 444.9$ cells $/ \mathrm{mm}^{2}$ in $\mathrm{p} 75 \mathrm{NTR}$ antibody-infused mice for the RMS; and $8212.0 \pm 1631.7$ cells/ $\mathrm{mm}^{2}$ in IgG-FC vs $16,177.2 \pm 254.4 \mathrm{cells} / \mathrm{mm}^{2}$ in p75NTRantibody-infused mice for the SVZ; $n=3$ animals; $p<0.001$ ) (Fig. 5C,D). These results demonstrate that BDNF-p75NTR interaction is important for the accumulation of neuronal precursors in the adult OB.

Recent studies have shown that TrkB haploinsufficient mice have a reduced number of BrdU ${ }^{+}$cells in the OB $28 \mathrm{~d}$ after BrdU injection (Bath et al., 2008). Whereas TrkB receptors are mostly found on astrocytes (Fig. 4C-G), low level of their expression is also detected in neuroblasts (Fig. 4C), and, from these experiments, it was not clear whether the reduced number of $\mathrm{BrdU}^{+}$ cells in the OB results from the alterations of TrkB expression on astrocytes or neuroblasts. To address this issue, we analyzed the number of $\mathrm{BrdU}^{+}$cells in the $\mathrm{RMS}_{\mathrm{OB}}$ of mice lacking TrkB expression in astrocytes. To produce these animals, we crossed animals bearing a floxed TrkB allele (Minichiello et al., 1999) with GlastCre::ERT2 mice (Mori et al., 2006), which carry tamoxifeninducible form of Cre in the GLAST locus. Because neuronal precursors are derived from GFAP-expressing cells (AlvarezBuylla and Garcia-Verdugo, 2002; Lledo and Saghatelyan, 2005) and, therefore, can be also affected in these transgenic animals, we performed all our analysis $5 \mathrm{~d}$ after the end of tamoxifen treatment. At this stage, only $4 \pm 2 \%$ of recombined neuroblasts (assessed by the Dcx immunoreactivity and the presence of the reporter protein in GlastCre::ERT2/ZEG mice) were present in the $\mathrm{RMS}_{\mathrm{OB}}$. In contrast, $69.6 \pm 8.8 \%$ of astrocytes were found to be recombined in the RMS, as it has been reported for the adult SVZ (Mori et al., 2006). Five days after BrdU injection, with BrdU being injected at the end of tamoxifen treatment, the number of $\mathrm{BrdU}^{+}$ cells was drastically reduced in the $\mathrm{RMS}_{\mathrm{OB}}$ of $\operatorname{TrkB}^{\mathrm{fl} / \mathrm{fl}}$ GLAST:: CreERT2 mice compared with the control TrkB ${ }^{\text {wildtype/wildtype }}$ 
GLAST::CreERT2 animals $\left(10,642.2 \pm 187.9\right.$ cells $/ \mathrm{mm}^{2}$ in wildtype vs $6560.0 \pm 89.7$ cells $/ \mathrm{mm}^{2}$ in TrkB ${ }^{\mathrm{f} / \mathrm{fl}}$ GLAST::CreERT2 mice; $n=4$ animals; $p<0.001$ ) (supplemental Fig. 4 , available at www. jneurosci.org as supplemental material). Because (1) this $40 \%$ reduction in the number of $\mathrm{BrdU}^{+}$cells cannot be explained by the $4 \%$ of recombined neuroblasts in the $\mathrm{RMS}_{\mathrm{OB}}$ and (2) cell proliferation and survival analyzed immediately after the end of tamoxifen treatment were not affected in the RMS and SVZ (data now shown), we conclude that TrkB receptors expressed on astrocytes play an important role in neuroblast migration in the RMS.

Our data show that application of TrkB-Fc reduced the number of $\mathrm{BrdU}^{+}$cells in the $\mathrm{OB}$ (Fig. 5C,D) and that endothelial cells are a likely candidate for the source of BDNF in the RMS (Fig. $3 A, B)$. To directly show that blood vessel-derived BDNF is involved in the arrival of newborn cells, we next attempted to downregulate its expression specifically in the blood vessels and only in adults. For this, we inserted a catheter connected to the $7 \mathrm{~d}$ osmotic minipump to the external carotid artery. Figure $5 E$ shows that, with this approach, fluorescently tagged BDNF siRNAs accumulate in blood vessels but not in other cell types of the adult brain. Importantly, infusion of BDNF siRNA reduces the expression of BDNF in the adult RMS by $38.45 \pm 10.6 \%$ (data were normalized for GFAP immunostaining; $n=3$ animals) (Fig. $5 F)$ that consequently decreased the number of $\mathrm{BrdU}^{+}$cells all along the SVZ-OB pathway $(n=3$ animals; $p<0.001)$ (Fig. $5 G)$. Although these data do not exclude possibility that endothelial cell-derived BDNF has also a nonmigratory role (such as cell proliferation, survival, and differentiation), the reduction in the $\mathrm{BrdU}^{+}$cells in the adult SVZ-OB was at least partially attributable to the immigration of these cells to neighboring territories, such as striatum $\left(0.5 \pm 0.3\right.$ cells $/ \mathrm{mm}^{2}$ in control vs $30.2 \pm 8.9$ cells $/ \mathrm{mm}^{2}$ in BDNF siRNA-treated animals) (Fig. $5 H$ ).

Altogether our in vivo experiments demonstrate that BDNF is important for the proper navigation of neuronal precursors in the adult brain and that p75NTR as well as TrkB receptors expressed on the astrocytes are involved in this process. However, the physiological mechanisms that govern neuronal migration are very complex (Fig. $2 C-F$ ), and, from our in vivo experiments, it is difficult to discern the direct and acute role of BDNF, TrkB, or p75NTR. We therefore directly tested whether BDNF, TrkB, and p75NTR affect neuronal migration, using time-lapse video microscopy in the acute slices of the adult mouse forebrain. Bath application of BDNF (10 ng/ml) increased the average distance covered by migrating cells, the number of cells in the migratory phase, and decreased the duration of the resting period (Fig. 6A-C) (Table 1) (supplemental Video 5, available at www. jneurosci.org as supplemental material). In contrast, application of TrkB-Fc $(1 \mu \mathrm{g} / \mathrm{ml})$ decreased the average distance covered by migrating cells, decreased the number of cells in the migratory phase, and increased the duration of the stationary period (Fig. 6C) (see also Fig. 7B; Table 1) (supplemental Video 6, available at www.jneurosci.org as supplemental material). Application of TrkB-Fc together with BDNF either slightly increased or decreased or had no effect on the migratory behavior of neuroblasts depending on the concentration of BDNF (supplemental Fig. 5, available at www.jneurosci.org as supplemental material). In agreement with our in vivo experiments with function-blocking antibodies for p75NTR, incubation of acute adult mouse forebrain slices in these antibodies $(20 \mu \mathrm{g} / \mathrm{ml})$ drastically reduced the average distance that cells migrated, decreased the number of cells in the migratory phase, and increased the duration of the stationary period (Fig. 6D-F; Table 1). Importantly, investigation of neuronal migration in the acute slices prepared from
p75NTR-deficient animals revealed very similar defects in migration (Fig. 6F-I; Table 1) (supplemental Video 7, available at www.jneurosci.org as supplemental material). The average distance that cells migrated as well as the number of cells in the migratory phase were drastically reduced, whereas the duration of the stationary period was increased. Moreover, bath application of BDNF (10 ng/ml), TrkB-Fc $(1 \mu \mathrm{g} / \mathrm{ml})$, or p75NTR function-blocking antibodies did not affect the migratory behavior of neuroblasts in the acute slices prepared from p75NTRdeficient animals (Fig. 6G-I; Table 1) (supplemental Video 7, available at www.jneurosci.org as supplemental material). These experiments suggest that p75NTR, but not TrkB receptors, expressed by neuroblasts control their migratory behavior. In agreement with these results are our observations showing that application of Trk inhibitor K252a (200 nM) did not affect the migration of neuronal precursors in the wild-type animals (Table 1) (supplemental Fig. 6, available at www.jneurosci.org as supplemental material). Despite the reductions in net migration observed, migration velocity was not altered after incubation of slices with p75NTR function-blocking antibodies, after application of BDNF and TrkB-FC, or in p75NTR-deficient animals (data not shown).

Finally, we tested vasculature-associated neuroblasts migration in vitro, in a tissue-engineered 3D connective tissue made of fibroblasts and endothelial cells, in which a network of BDNFexpressing capillary-like tubes mimicking blood capillaries, is formed (Berthod et al., 2006) (Fig. 6J). Coculturing of GFP ${ }^{+}$ neuroblasts with reconstituted capillaries showed that most of the migrating cells ( $78.6 \pm 6.9 \% ; n=52$ cells of 3 cultures) accumulate along the BDNF-expressing vessels (Fig. $6 K, L$ ). Time-lapse video imaging of cell migration in culture revealed a twofold increase in the distance of migration for the neuroblasts located close to the capillaries compared with those cocultured with fibroblasts alone $(0.12 \pm 0.01 \mu \mathrm{m} / 15 \mathrm{~s}$ in capillary culture, $n=41$ cells of 4 cultures vs $0.05 \pm 0.01 \mu \mathrm{m} / 15 \mathrm{~s}$ in fibroblasts cultures, $n=15$ cells of 3 cultures; $p<0.001$ ) (Fig. $6 M$ ). Reducing BDNF expression in the endothelial cells of capillaries by siRNA (Fig. 6M, inset) strongly reduced the proportion of capillary-associated migrating cells $(57.9 \pm 8.1 \% ; n=32$ cells of 3 cultures) and the mean distance that neuroblasts propagate $(0.12 \pm 0.01 \mu \mathrm{m} / 15 \mathrm{~s}$ in control siRNA, $n=12$ cells of 3 cultures vs $0.08 \pm 0.01 \mu \mathrm{m} / 15 \mathrm{~s}$ in BDNF siRNA, $n=15$ cells of 3 cultures; $p<0.001$ ) (Fig. 6M). Blocking p75NTR receptors on neuroblasts with function-blocking antibodies also decreased the migration of neuronal precursors $(0.12 \pm 0.01 \mu \mathrm{m} / 15 \mathrm{~s}$ in IgG-Fc, $n=10$ cells of 3 cultures vs $0.08 \pm 0.01 \mu \mathrm{m} / 15 \mathrm{~s}$ in p75NTR functionblocking antibodies, $n=16$ cells of 3 cultures; $p<0.001$ ) (Fig. $6 M)$.

Altogether, our in vitro data in the acute slices of the adult mouse forebrain as well as in the tissue-engineered capillaries clearly demonstrate that BDNF fosters neuronal migration in a p75NTR-dependent manner. But what is the role of astrocytes in the vasculature-associated neuroblasts migration, why BDNF is trapped by the RMS astrocytes, and why did conditional removal of TrkB in the astrocytes reduce the number of $\mathrm{BrdU}^{+}$cells in the $\mathrm{OB}$ ?

\section{Role of astrocytes in the vasculature-associated migration of} the adult neuronal precursors

BDNF secretion is a $\mathrm{Ca}^{2+}$-dependent process (Goggi et al., 2003), and, in some brain regions, BDNF bound to cell-surface TrkB receptors on astrocytes can be released into extracellular environment (Rubio, 1997; Alderson et al., 2000). It is, thus, conceivable 
Table 1. Migration of neuronal precursors and $\mathrm{Ca}^{2+}$ fluctuations in astrocytes in the acute slices of the adult mouse forebrain

\begin{tabular}{|c|c|c|c|c|c|c|c|}
\hline Experiment & & $\begin{array}{l}\text { Distance of migra- } \\
\text { tion ( } \mu \mathrm{m})\end{array}$ & $\begin{array}{l}\text { Cells in the migra- } \\
\text { tory phase (\%) }\end{array}$ & $\begin{array}{l}\text { Duration of the } \\
\text { resting period (s) }\end{array}$ & $\begin{array}{l}\text { Rate of migration } \\
(\mu \mathrm{m} / \mathrm{h})\end{array}$ & $\begin{array}{l}\text { Frequency of } \mathrm{Ca}^{2+} \\
\text { fluctuations } \\
\text { (peak/min) }\end{array}$ & $\begin{array}{l}\text { Number of cells/slices/ } \\
\text { animals }\end{array}$ \\
\hline Migration in the RMS control & & $0.32 \pm 0.02$ & $47.4 \pm 2.0$ & $492.3 \pm 41.5$ & $121.2 \pm 3.9$ & & $64 / 14 / 10$ \\
\hline Application of BDNF (10 ng/ml) & $\begin{array}{l}\text { Ctrl } \\
\text { BDNF }\end{array}$ & $\begin{array}{l}0.34 \pm 0.01 \\
0.43 \pm 0.02^{*}\end{array}$ & $\begin{array}{l}44.9 \pm 2.0 \\
57.4 \pm 1.2^{*}\end{array}$ & $\begin{array}{l}274.2 \pm 13.8 \\
147.5 \pm 5.6^{*}\end{array}$ & $\begin{array}{l}136.4 \pm 5.2 \\
142.6 \pm 6.9\end{array}$ & & $376 / 4 / 4$ \\
\hline Application of TrkB-Fc (1 $\mu \mathrm{g} / \mathrm{ml})$ & $\begin{array}{l}\lg G-F c \\
\text { TrkB-Fc }\end{array}$ & $\begin{array}{l}0.33 \pm 0.02 \\
0.16 \pm 0.04^{*}\end{array}$ & $\begin{array}{l}49.4 \pm 2.1 \\
24.3 \pm 6.2^{*}\end{array}$ & $\begin{array}{l}260.5 \pm 12.7 \\
713.2 \pm 160.0^{*}\end{array}$ & $\begin{array}{r}115.7 \pm 7.3 \\
88.3 \pm 8.8\end{array}$ & & $\begin{array}{l}162 / 4 / 4 \\
194 / 4 / 4\end{array}$ \\
\hline Application of p75NTR $(20 \mu \mathrm{g} / \mathrm{ml})$ & $\begin{array}{l}\lg \mathrm{G}-\mathrm{Fc} \\
\mathrm{p} 75 \mathrm{NTR}\end{array}$ & $\begin{array}{l}0.33 \pm 0.03 \\
0.16 \pm 0.01^{*}\end{array}$ & $\begin{array}{l}47.0 \pm 3.3 \\
24.6 \pm 1.1^{*}\end{array}$ & $\begin{array}{l}243.6 \pm 28.1 \\
558.7 \pm 2.9^{* *}\end{array}$ & $\begin{array}{l}121.1 \pm 6.7 \\
101.5 \pm 6.6\end{array}$ & & $\begin{array}{l}91 / 4 / 4 \\
138 / 5 / 3\end{array}$ \\
\hline Application of K252a (200 nm) & $\begin{array}{l}\text { Ctrl } \\
\mathrm{K} 252 \mathrm{a}\end{array}$ & $\begin{array}{l}0.33 \pm 0.05 \\
0.30 \pm 0.06\end{array}$ & $\begin{array}{l}48.3 \pm 7.9 \\
44.4 \pm 6.9\end{array}$ & $\begin{array}{l}293.5 \pm 44.2 \\
294.5 \pm 55.9\end{array}$ & $\begin{array}{l}135.3 \pm 4.1 \\
127.1 \pm 1.9\end{array}$ & & $125 / 2 / 2$ \\
\hline $\begin{array}{l}\text { p75NTR-WT } \\
\text { p75NTR-K0 }\end{array}$ & & $\begin{array}{l}0.33 \pm 0.01 \\
0.18 \pm 0.03^{*}\end{array}$ & $\begin{array}{l}47.1 \pm 1.4 \\
26.9 \pm 4.2^{* *}\end{array}$ & $\begin{array}{l}259.4 \pm 10.9 \\
735.1 \pm 101.1^{* *}\end{array}$ & $\begin{array}{l}124.4 \pm 4.3 \\
121.7 \pm 8.4\end{array}$ & & $\begin{array}{l}150 / 5 / 4 \\
200 / 6 / 6\end{array}$ \\
\hline $\begin{array}{l}\text { Application of BDNF }(10 \mathrm{ng} / \mathrm{ml}) \text { in } \\
\text { p75NTR-K0 }\end{array}$ & $\begin{array}{l}\text { Ctrl } \\
\text { BDNF }\end{array}$ & $\begin{array}{l}0.19 \pm 0.06 \\
0.2 \pm 0.06\end{array}$ & $\begin{array}{l}25.2 \pm 6.4 \\
26.2 \pm 7.1\end{array}$ & $\begin{array}{l}750.5 \pm 158.4 \\
760.0 \pm 156.3\end{array}$ & $\begin{array}{l}121.7 \pm 13.3 \\
125.9 \pm 10.3\end{array}$ & & $168 / 4 / 4$ \\
\hline $\begin{array}{l}\text { Application of TrkB-Fc }(1 \mu \mathrm{g} / \mathrm{ml}) \text { in } \\
\text { p75NTR-K0 }\end{array}$ & $\begin{array}{l}\text { Ctrl } \\
\text { TrkB-Fc }\end{array}$ & $\begin{array}{l}0.18 \pm 0.06 \\
0.18 \pm 0.02\end{array}$ & $\begin{array}{l}30.1 \pm 1.9 \\
28.8 \pm 2.1\end{array}$ & $\begin{array}{l}704.2 \pm 38.4 \\
721.8 \pm 21.1\end{array}$ & $\begin{array}{l}121.6 \pm 2.7 \\
122.4 \pm 11.4\end{array}$ & & $88 / 2 / 2$ \\
\hline $\mathrm{Ca}^{2+}$ activity in the RMS control & & & & & & $0.49 \pm 0.0004$ & $125 / 27 / 10$ \\
\hline Application of GABA (10 $\mu \mathrm{M})$ & $\begin{array}{l}\text { Ctrl } \\
\text { GABA }\end{array}$ & $\begin{array}{l}0.41 \pm 0.04 \\
0.17 \pm 0.04^{* *}\end{array}$ & $\begin{array}{l}55.7 \pm 2.9 \\
28.1 \pm 5.1^{*}\end{array}$ & $\begin{array}{l}262.0 \pm 33.7 \\
584.6 \pm 16.1^{* *}\end{array}$ & $\begin{array}{r}110.8 \pm 10.6 \\
79.8 \pm 7.9^{*}\end{array}$ & $\begin{array}{l}0.42 \pm 0.001 \\
0.58 \pm 0.001^{* *}\end{array}$ & $\begin{array}{l}27 / 4 / 3 \text { for } \mathrm{Ca}^{2+} \text { activity } \\
146 / 5 / 5 \text { for migration }\end{array}$ \\
\hline $\begin{array}{l}\text { Application of bicuculline metho- } \\
\text { chloride (100 } \mu \mathrm{m})\end{array}$ & $\begin{array}{l}\text { Ctrl } \\
\mathrm{Bic}\end{array}$ & $\begin{array}{l}0.24 \pm 0.01 \\
0.35 \pm 0.03^{*}\end{array}$ & $\begin{array}{l}40.6 \pm 1.8 \\
51.5 \pm 2.8^{*}\end{array}$ & $\begin{array}{l}255.0 \pm 27.3 \\
168.0 \pm 17.7^{*}\end{array}$ & $\begin{array}{c}93.8 \pm 3.9 \\
135.3 \pm 6.9^{*}\end{array}$ & $\begin{array}{l}0.52 \pm 0.0007 \\
0.32 \pm 0.001^{*}\end{array}$ & $\begin{array}{l}53 / 7 / 5 \text { for } \mathrm{Ca}^{2+} \text { activity } \\
130 / 7 / 5 \text { for migration }\end{array}$ \\
\hline $\begin{array}{l}\text { Application of TrkB-Fc }(1 \mu \mathrm{g} / \mathrm{ml})- \\
\text { TrkB-Fc }(1 \mu \mathrm{g} / \mathrm{ml})\end{array}$ & TrkB-Fc & $0.19 \pm 0.04$ & $28.5 \pm 5.8$ & $814.0 \pm 79.0$ & $109.1 \pm 2.5$ & & $67 / 2 / 2$ \\
\hline $\begin{array}{l}\text { Application of TrkB-Fc }(1 \mu \mathrm{g} / \mathrm{ml})- \\
\text { GABA (10 } \mu \mathrm{m})\end{array}$ & GABA & $0.16 \pm 0.06$ & $25.5 \pm 9.0$ & $864.5 \pm 281.0$ & $114.3 \pm 4.5$ & & $105 / 2 / 2$ \\
\hline $\begin{array}{l}\text { Application of GABA (10 } \mu \mathrm{m})- \\
\text { TrkB-Fc }(1 \mu \mathrm{g} / \mathrm{ml})\end{array}$ & $\begin{array}{l}\text { GABA } \\
\text { TrkB-Fc }\end{array}$ & $\begin{array}{l}0.14 \pm 0.02 \\
0.11 \pm 0.0001\end{array}$ & $\begin{array}{l}26.1 \pm 4.7 \\
19.9 \pm 0.06\end{array}$ & $\begin{array}{l}704.6 \pm 8.8 \\
781.2 \pm 9.8\end{array}$ & $\begin{array}{l}111.5 \pm 11.6 \\
109.1 \pm 3.4\end{array}$ & & $71 / 2 / 2$ \\
\hline Application of 2-APB $(100 \mu \mathrm{M})$ & $\begin{array}{l}\text { Ctrl } \\
2-A P B\end{array}$ & $\begin{array}{l}0.32 \pm 0.05 \\
0.01 \pm 0.001^{* *}\end{array}$ & $\begin{array}{c}48.4 \pm 0.3 \\
1.1 \pm 1.1^{*}\end{array}$ & $\begin{array}{l}276.5 \pm 16.2 \\
738.0 \pm 37.9\end{array}$ & $\begin{aligned} 120.5 & \pm 2.8 \\
87.5 & \pm 0.3^{*}\end{aligned}$ & $\begin{array}{l}0.46 \pm 0.048 \\
0.08 \pm 0.025^{* * *}\end{array}$ & $\begin{array}{l}\text { 40/4/4 for } \mathrm{Ca}^{2+} \text { activity } \\
45 / 2 / 2 \text { for migration }\end{array}$ \\
\hline
\end{tabular}

Bic, Bicuculline; Ctrl, control; KO, knock out; WT, wild type.

that, in the RMS, $\mathrm{Ca}^{2+}$ activity in astrocytes may induce secretion of BDNF or release BDNF from cell-surface TrkB receptors. $\mathrm{Ca}^{2+}$ activity has also been implicated in the trafficking of TrkB to the plasma membrane (Du et al., 2003), and it is possible that $\mathrm{Ca}^{2+}$ fluctuations in the astrocytes induce TrkB insertion at the cell surface and thereby restrict the amount of extracellular BDNF available to neuroblasts. These potential links between $\mathrm{Ca}^{2+} \mathrm{ac}-$ tivity and BDNF level led us to test whether adult RMS astrocytes display $\mathrm{Ca}^{2+}$ fluctuations and, if so, whether they regulate BDNF level available to migrating neuroblasts.

We loaded acute slices of the adult mouse forebrain with membrane-permeable $\mathrm{Ca}^{2+}$ indicator Fluo4-AM. This indicator specifically enters astrocytes, but not neuroblasts, as revealed by the fact that, during the entire recording time (sometimes $>2 \mathrm{~h}$ ), none of the GFAP-expressing (data not shown) Fluo4-AMloaded cells had migrated. Our $\mathrm{Ca}^{2+}$ imaging studies demonstrate that RMS astrocytes and their processes display spontaneous $\mathrm{Ca}^{2+}$ fluctuations (Fig. 7A) (supplemental Videos 8, 9, available at www.jneurosci.org as supplemental material) with the mean frequency of $0.49 \pm 0.004$ peaks $/ \mathrm{min}(n=125$ cells from 10 animals). Having shown spontaneous $\mathrm{Ca}^{2+}$ fluctuations in RMS astrocytes, we next asked, what triggers $\mathrm{Ca}^{2+}$ activity in these glial cells? Because (1) GABA depolarizes astrocytes and induces an increase in intracellular $\left[\mathrm{Ca}^{2+}\right]$ (Fraser et al., 1995), (2) astrocytes in the SVZ and RMS express functional GABA receptors (Liu et al., 2005), and (3) migrating neuroblasts release GABA (Bolteus and Bordey, 2004), we hypothesized that migrating neuroblasts themselves control $\mathrm{Ca}^{2+}$ activity in the astrocytes via GABAergic signaling.

To investigate the role of GABA in the triggering of $\mathrm{Ca}^{2+}$ activity in astrocytes, we applied GABA $(10 \mu \mathrm{M})$ or the $\mathrm{GABA}_{\mathrm{A}}$ receptor antagonist bicuculline methochloride $(100 \mu \mathrm{M})$ to Fluo4-AM-loaded adult mouse forebrain slices and then performed combined real-time video imaging of $\mathrm{Ca}^{2+}$ fluctuations in astrocytes and neuroblasts migration. Application of GABA increased the frequency of $\mathrm{Ca}^{2+}$ fluctuations in astrocytes (Table 1) (supplemental Video 8, available at www.jneurosci.org as supplemental material) and decreased the average distance that migrating cells propagated, reduced the number of cells in the migratory phase, and increased the duration of the stationary period (Table 1). In contrast, bicuculline application drastically reduced the frequency of $\mathrm{Ca}^{2+}$ fluctuations in astrocytes (Fig. 7A; Table 1) (supplemental Video 9, available at www.jneurosci.org as supplemental material) and increased the migration of neuronal precursors (Table 1). The application of bicuculline not only increased the rate of migration of neuronal precursors by $44.6 \pm$ 
A

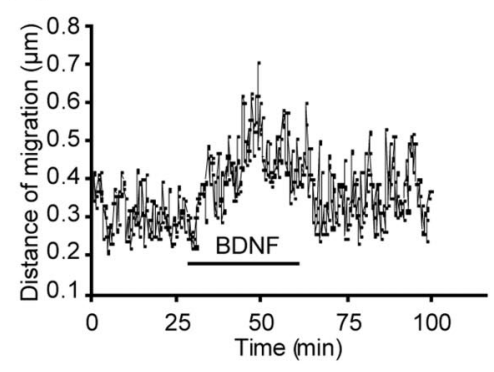

D
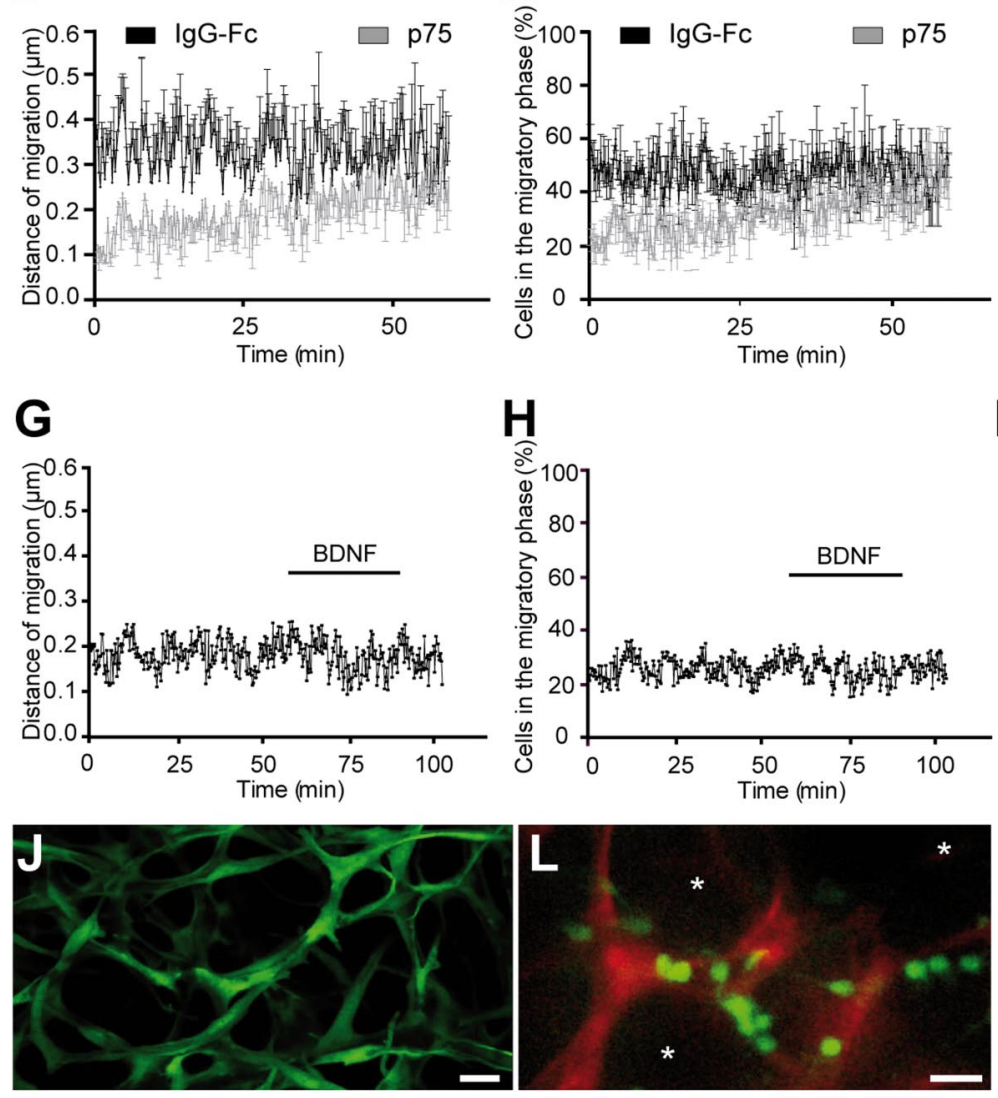

E
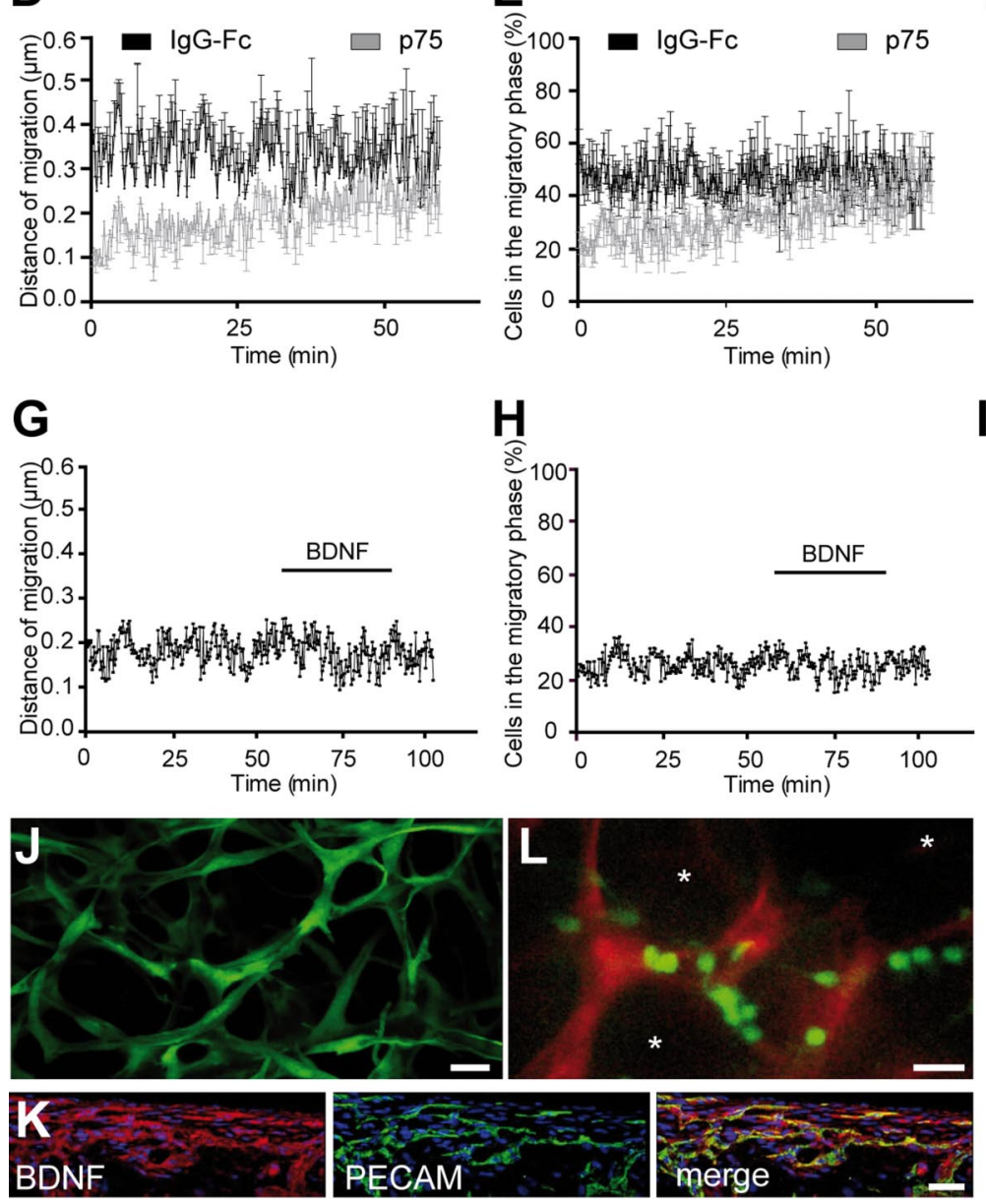

C
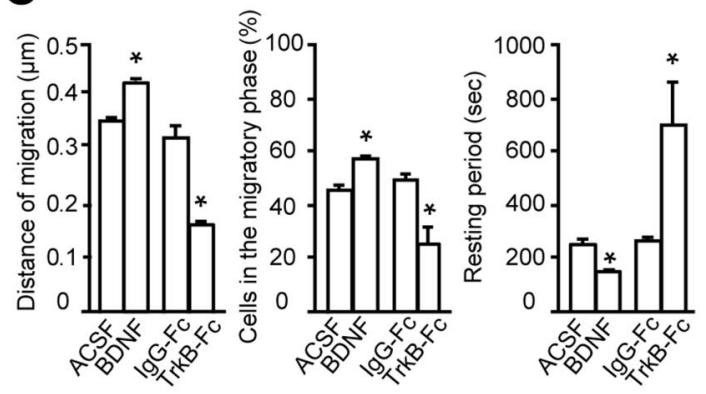

F
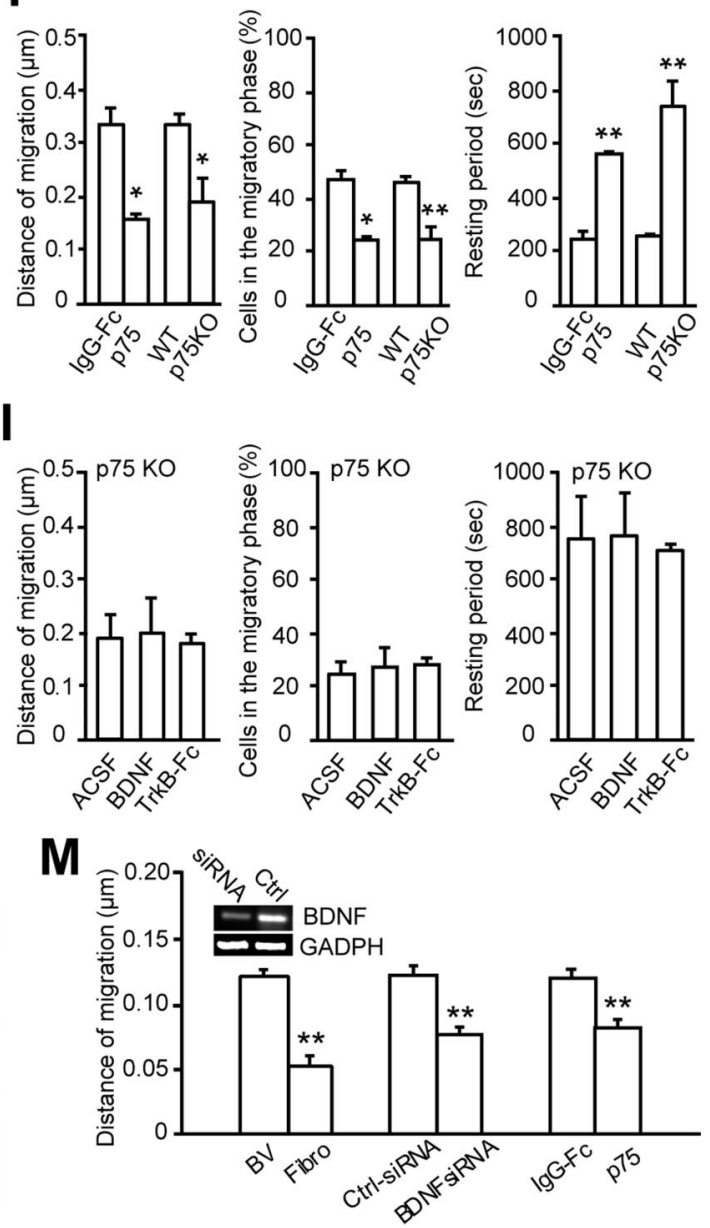

Figure 6. BDNF fosters neuronal migration via p75NTR. $\boldsymbol{A}, \boldsymbol{B}$, Individual experiment demonstrating that bath application of BDNF (10 ng/ml) increases the average distance that migrating cells propagate $(\boldsymbol{A})$ and raises the percentage of cells that are in the migratory phase at each time point $(\boldsymbol{B})$. The time period for BDNF application is shown by a black line. $\boldsymbol{C}$, Summary graph showing the effect of BDNF or TrkB-Fc $(1 \mu \mathrm{g} / \mathrm{ml})$ applications on the average distance that migratory cells propagate (per $15 \mathrm{~s}$ ), the percentage of cells in the migratory phase, and the duration of the stationary period. In control experiments, lgG-Fc (1 $\mu \mathrm{g} / \mathrm{ml})$ was applied instead of TrkB-Fc. D, E, Summary graphs showing that preincubation of slices with p75NTR function-blocking antibodies drastically decreases the average distance that migrating cells propagate $(\boldsymbol{D})$ and reduces percentage of cells in the migratory phase at each time point $(\boldsymbol{E})$. The time-lapse recording was performed after preincubation of slices in either p75NTR function-blocking antibodies or lgG-Fc ( $20 \mu \mathrm{g} / \mathrm{ml})$ for $1 \mathrm{~h}$. During the entire period of recording, the slices were continuously perfused with oxygenated ACSF ( $2 \mathrm{ml} / \mathrm{min})$. Note that the blocking effect of p75NTR function-blocking antibodies is washed out during recording. $\boldsymbol{F}$, Summary graph showing that deficiency in p75NTR and application of p75NTR function-blocking antibodies affects the average distance that migratory cells propagate (per $15 \mathrm{~s}$ ), the percentage of cells in the migratory phase, and the duration of the stationary period. $\boldsymbol{G}, \boldsymbol{H}$, Individual experiment demonstrating that bath application of BDNF $(10 \mathrm{ng} / \mathrm{ml})$ does not affect the average distance that migrating cells propagate $(\boldsymbol{G})$ and the percentage of cells in the migratory phase at each time point $(\boldsymbol{H})$ in the slices prepared from p75NTR-deficient animals. I, Summary graph showing the absence of effect of BDNF and TrkB-Fc applications on the average distance that migratory cells propagate (per $15 \mathrm{~s}$ ), the percentage of cells in the migratory phase, and the stationary period duration in p75NTR-deficient animals. J, Micrograph illustrating GFP ${ }^{+}$tissueengineered 3D capillary-like network in vitro. Scale bar, $30 \mu \mathrm{m} . \boldsymbol{K}$, Immunostaining for BDNF (red) and PECAM (green) in the transversal sections of sponges containing capillary-like network. Scale bar, $50 \mu \mathrm{m}$. L, Micrograph depicting GAD67-GFP ${ }^{+}$neuroblasts (green) cocultured in 3D capillary-like network (red). HUVEC cells were transduced with GFP lentivirus. GFP ${ }^{+}$neuroblasts (small cells of 5-10 $\mu \mathrm{m}$ size) and GFP ${ }^{+}$capillaries (long tubular-like structures) were easily distinguishable on the basis of their shapes and were false-colored in offline analysis using ImagePro software. Note that neuroblasts accumulate along the capillaries, and places that do not contain these capillary-like structures (asterisks) are also free of neuroblasts. Scale bar, $20 \mu \mathrm{m}$. $\boldsymbol{M}$, Quantification of neuroblast migration in the capillary-like network under different experimental conditions. Note the increased migration of neuronal precursors in the cultures containing capillary-like structure compared with the control fibroblast containing cultures (Fibro). Note also that BDNF siRNA and p75NTR function-blocking antibodies reduce the migration of neuronal precursors. Distance of migration (per 15s) was calculated in the images acquired every $15 \mathrm{~s}$ for at least $1 \mathrm{~h}$. Inset shows semiquantitative RT-PCR analysis of BDNF expression in the endothelial cells after siRNA transfection. KO, Knock-out; WT, wild type; BV, blood vessels. 


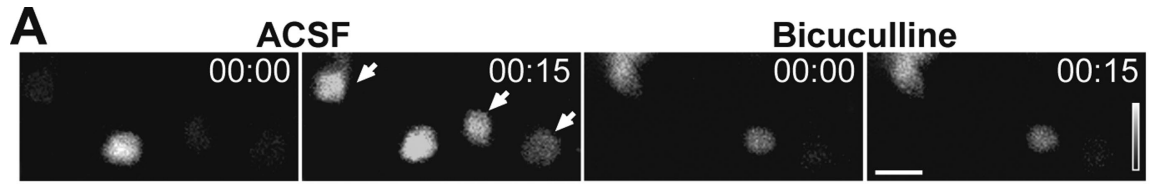

B
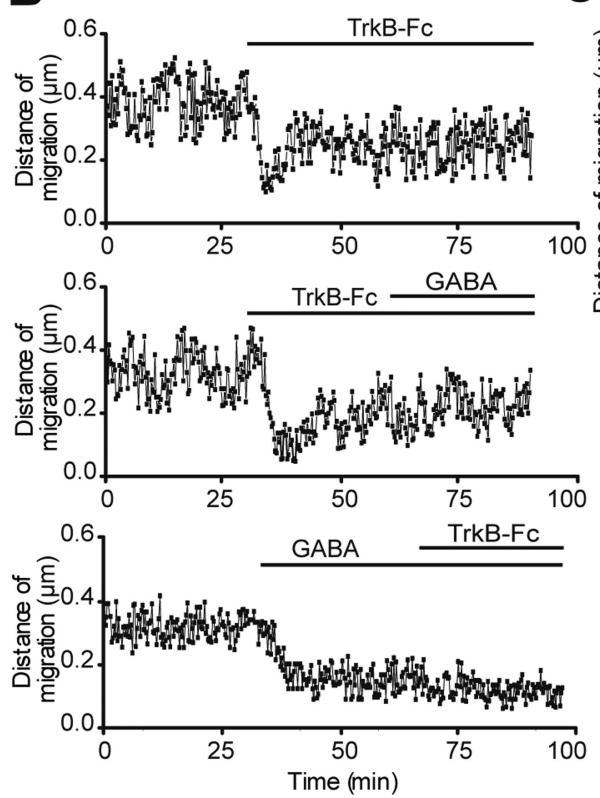

C
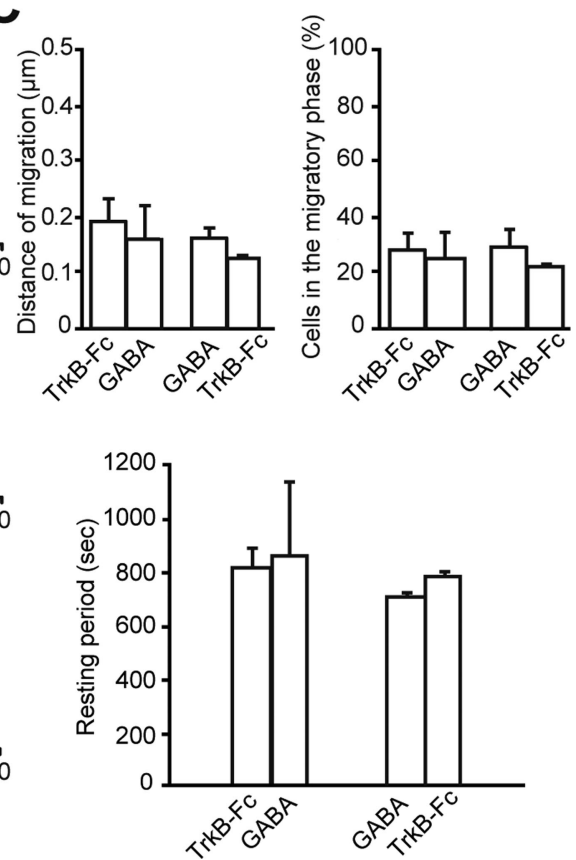

Figure 7. GABAergic signaling affects $\mathrm{Ca}^{2+}$ activity in astrocytes and migration of neuroblasts. $A$, Application of $\mathrm{GABA}_{\mathrm{A}}$ receptor antagonist bicuculline (Bic, $100 \mu \mathrm{m}$ ) diminishes spontaneous $\mathrm{Ca}^{2+}$ fluctuations in the astrocytes. Time-lapse video imaging illustrating changes in the fluorescent intensity under control conditions (left panels) and after application of bicuculline (right panels) over time (indicated in seconds in the top right corner of each photograph). Scale bar, $10 \mu \mathrm{m}$. $\boldsymbol{B}$, Individual experiments demonstrating that bath application of GABA (10 $\mu \mathrm{m})$ after application of TrkB-Fc $(1 \mu \mathrm{g} / \mathrm{ml})$ as well as TrkB-Fc application after $\mathrm{GABA}$ application do not affect the average distance that migrating cells propagate. The time periods for TrkB-Fc and GABA applications are shown by black lines. Each time point represents the average value for $20-30$ cells. C, Summary graphs illustrating that bath application of GABA (10 $\mu \mathrm{m})$ after application of TrkB-Fc (1 $\mu \mathrm{g} / \mathrm{ml})$ and bath application of TrkB-Fc (1 $\mu \mathrm{g} / \mathrm{ml}$ ) after application of GABA (10 $\mu \mathrm{m})$ do not affect the average distance that migrating cells propagate (per $15 \mathrm{~s}$ ), the percentage of cells in the migratory phase, and the duration of stationary period.

$5.7 \%$ (Table 1), as reported previously (Bolteus and Bordey, 2004), but also significantly augmented the average distance that migrating cells propagated, increased the number of cells in the migratory phase and decreased the duration of the stationary period (Table 1). The $\mathrm{Ca}^{2+}$ fluctuations in astrocytes were most likely mediated by $\mathrm{IP}_{3}$-sensitive intracellular $\mathrm{Ca}^{2+}$ stores, because preapplication of 2-aminoethoxydiphenyl borate (2-APB) (100 $\mu \mathrm{M})$ abolished the effect of bicuculline and GABA on the $\mathrm{Ca}^{2+}$ activity in astrocytes (supplemental Fig. 7, available at www.jneurosci.org as supplemental material). Thus, manipulation with GABAergic signaling in the adult RMS affects $\mathrm{Ca}^{2+}$ activity in the astrocytes and neuronal precursor migration in the manner that is reminiscent of the BDNF signaling manipulation. We, therefore, decided to investigate whether effect of GABA on the migration of neuronal precursors involves the BDNF pathway. For this, we first blocked BDNF pathway by application of TrkB-Fc (1 $\mu \mathrm{g} / \mathrm{ml})$ and then applied GABA $(10 \mu \mathrm{M})$ (Fig. $7 B)$. Under these conditions, GABA had no effect on the migratory behavior of neuroblasts (Fig. 7B,C; Table 1). Conversely, preapplication of GABA decreased the migration of neuronal precursors that was not possible to further reduce by application of TrkB-Fc (Fig. $7 \mathrm{~B}, \mathrm{C}$; Table 1 ). These experiments suggest that BDNF and GABA control cell migration via the same pathway.
We then asked whether GABA-induced $\mathrm{Ca}^{2+}$ fluctuation in astrocytes might regulate local delivery of BDNF to neuroblasts. To address this, we prepared cultures of astrocytes from the adult SVZ. These cultures contain mostly astrocytes, as verified by the labeling for GFAP, Tuj1, and receptor-interacting protein, markers for astrocytes, neurons, and oligodendrocytes, respectively, and are immunopositive for TrkB (data not shown). To investigate whether $\mathrm{Ca}^{2+}$ activity in astrocytes induces BDNF release, we first preincubated these cultures with BDNF (10 ng/ $\mathrm{ml}$ ), washed extensively, and then treated with $10 \mu \mathrm{M}$ GABA for $30 \mathrm{~min}$. Activation of $\mathrm{GABA}_{\mathrm{A}}$ receptors on astrocytes did not change the amount of secreted BDNF in these cultures $(92.7 \pm 5.9 \%$ of control; $n=$ 3 ), indicating that GABA does not induce release of BDNF from astrocytes.

We then tested whether GABAinduced $\mathrm{Ca}^{2+}$ fluctuation in astrocytes might regulate trafficking of $\operatorname{TrkB}$ receptors and thereby control the amount of extracellular BDNF available to neuroblasts. We incubated acute adult mouse forebrain slices with bicuculline $(100 \mu \mathrm{M})$ or GABA $(10 \mu \mathrm{M})$ for $1 \mathrm{~h}$, extracted the RMS, and analyzed surface TrkB receptor level by cell-surface biotinylation of the dissociated cells. Incubation of slices with bicuculline reduced the amount of TrkB receptors located at the surface of RMS cells to $77.4 \pm 2.5 \%$ of control levels $(n=4$ animals; $p<0.05$ ) (Fig. $8 A$ ), whereas treatment with GABA $(10 \mu \mathrm{M})$ increased their amount to $122.4 \pm 5.1 \%(n=4$ animals; $p<0.05$ ) (Fig. 8 A). Interestingly, blocking $\mathrm{Ca}^{2+}$ fluctuations in astrocytes by 2-APB $(100 \mu \mathrm{M})$ reduced the amount of TrkB receptors located at the surface to $63.2 \pm 10.1 \%(n=3$ animals; $p<0.05)$ (Fig. $8 A)$. It is also noteworthy that incubation of slices with BDNF $(10 \mathrm{ng} / \mathrm{ml})$ for $1 \mathrm{~h}$ decreased the amount of surface TrkB receptors to $77.9 \pm$ $6.5 \%(n=3$ animals; $p<0.05)$ (Fig. $8 A$ ).

These data suggest that modulation of $\mathrm{Ca}^{2+}$ fluctuations in astrocytes by endogenous GABAergic signaling is required for plasma membrane insertion of TrkB receptors and that binding of BDNF to this receptor induces its internalization. If endogenous GABAergic signaling induces the insertion of TrkB receptors on the plasma membrane, then blocking $\mathrm{GABA}_{\mathrm{A}}$ receptors with bicuculline should decrease trapping of BDNF by astrocytes. Indeed, BDNF immunostaining in slices previously incubated with bicuculline $(100 \mu \mathrm{M})$ for $1 \mathrm{~h}$ induced a twofold reduction in BDNF labeling (51.05 $\pm 0.4 \%$ decrease; data were normalized for GFAP immunostaining; $n=3$ animals) (Fig. $8 B$ ). These results suggest that GABAergic signaling from neuroblasts facilitates insertion of TrkB on the plasma membrane of RMS astrocytes. The newly inserted TrkB receptor is then able to bind to BDNF and therefore might act to reduce BDNF availability for migrating neuronal precursors. Through this pathway, neuroblasts might control the periodicity of their migratory and stationary phases and thus their own migration. 
A
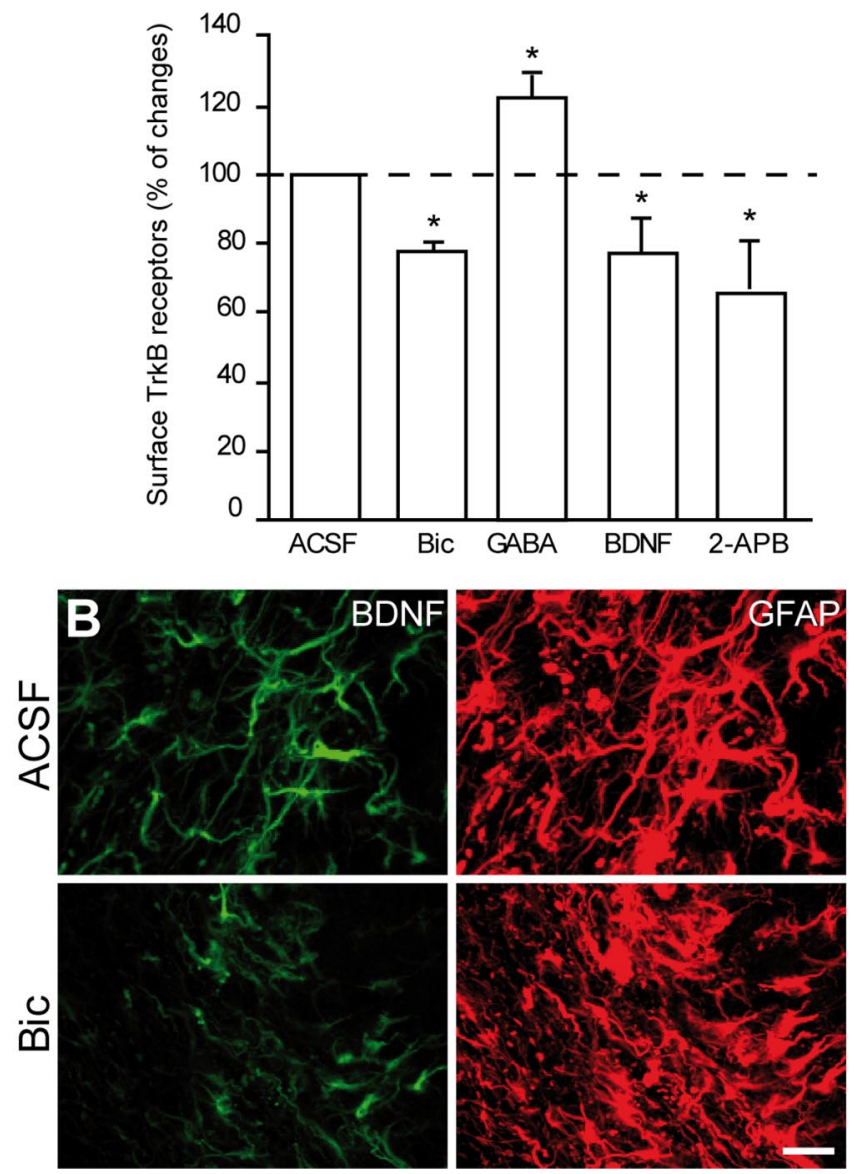

Figure 8. GABA induces insertion of TrkB receptors on membrane of astrocytes. $A$, Preincubation of slices with bicuculline (Bic; $100 \mu \mathrm{m}), \operatorname{BDNF}(10 \mathrm{ng} / \mathrm{ml})$, or 2-APB $(100 \mu \mathrm{m})$ for $1 \mathrm{~h}$ reduces amount of surface TrkB receptors. In contrast, treatment with GABA (10 $\mu \mathrm{m}$ for $1 \mathrm{~h}$ ) increases the amount of surface TrkB receptors. The cell-surface molecules of freshly isolated cells, extracted from RMS, were labeled with Sulfo-NHS-biotin. Cell lysates were precipitated with streptavidin-coated agarose beads and immunolabeled with TrkB antibodies. The amount of surface TrkB receptors was analyzed by ELISA. $\boldsymbol{B}$, Incubation of acute slices of the adult mouse forebrain with bicuculline $(100 \mu \mathrm{m})$ decreases immunolabeling for BDNF in the adult RMS. Scale bar, $10 \mu \mathrm{m}$.

\section{Discussion}

The present study has demonstrated that blood vessels provide structural organization and molecular cues important for neuroblast migration in the adult brain. Our data reveal that vasculature parallels the migratory stream of neuronal precursors and guides them toward and into OB. We also discovered the underlying mechanism of vasculature-associated migration of neuronal precursors. Our data suggest that the endothelial cells of blood vessels constitutively synthesize BDNF, which is released within the extracellular space and fosters neuronal migration via p75NTR expressed by these migrating cells. We hypothesize that migrating neuroblasts control their own migration by regulating the amount of free extracellular BDNF. GABA released from neuronal precursors induces $\mathrm{Ca}^{2+}$-dependent insertion of highaffinity TrkB receptors into the plasma membrane of astrocytes that ensheath migrating neuroblasts and contact blood vessels. This leads to trapping of extracellular BDNF and, therefore, might foster the entry of migrating cells to the stationary phase. Together, our data highlight an unexpected organization of blood vessels in the adult migratory stream and provide a func- tional and mechanistic explanation for the long-distance saltatory migration of neuronal precursors from the posterior (SVZ) to the most anterior $(\mathrm{OB})$ parts of the adult brain (for a model, see Fig. $2 H$ ).

\section{Blood vessels as a substrate for a long-distance migration of newborn cells in the adult brain}

The mechanisms of long-distance migration of neuronal precursors in the adult brain have remained elusive. Neuronal precursors were generally assumed to course from the SVZ toward and into the $\mathrm{OB}$ in response to chemoattractive molecules, whereas chemorepellent cues were thought to keep these cells in the migratory stream and impede their invasion of neighboring territories. Although in vitro studies suggested the existence of such chemoattractive cues (Ng et al., 2005; Paratcha et al., 2006), surgical removal of the $\mathrm{OB}$ in vivo did not affect migration of neuronal precursors (Jankovski et al., 1998; Kirschenbaum et al., 1999). With regard to the chemorepellent molecules, it has been demonstrated that the septum (Wu et al., 1999) and the choroid plexus (Sawamoto et al., 2006) secrete Slit, a molecule that repels neuronal precursors from the posterior parts of the brain. The gradient of Slit is created by the beating of cilia of the ependymal cells bordering lateral ventricle (Sawamoto et al., 2006). Although this gradient is important for the navigation of migrating cells in the SVZ (Sawamoto et al., 2006), it is difficult to imagine how the unidirectional vectorial gradient of a single molecule might explain the complex-shaped curvature migration of newborn cells in the RMS. For newborn cells to remain in the RMS and migrate through various brain regions toward and into $\mathrm{OB}$, all RMS-neighboring territories would have to secrete chemorepellent guidance cues. However, because the adult migratory stream has a very complex curvature architecture, gradients of many different chemorepellent molecules would be required to ensure faithful migration of newborn cells (Fig. $2 H$ ). The vasculature-guided migration hypothesis proposed here offers a much simpler and cogent explanation of the functional organization of the long-distance journey of newborn cells from caudal to the most rostral parts of the forebrain (for a model, see Fig. $2 \mathrm{H}$ ). This hypothesis allows us to envisage the organization of the migratory pathway in the adult forebrain without a requirement for myriad chemoattractive, chemorepellent, and chemopermissive cues. In the context of newborn cells migrating along blood vessels, a single repellent molecule might be sufficient to push cells away from the posterior parts of the brain (Wu et al., 1999; Sawamoto et al., 2006), with vasculature providing local cues (BDNF and likely many others) to keep migrating precursors in the RMS and guide them in the adult forebrain. In such a perspective, the major difficulty for migrating cells is to "jump" in the core of the OB from the blood vessels oriented parallel to the tangentially migrating cells to the ones that are oriented perpendicularly and start thereafter radial migration. It seems that this is indeed a difficult task for migrating cells because many of them become lost and detached from vasculature in the core of $\mathrm{OB}$. However, the cells that succeed in exiting from the $\mathrm{RMS}_{\mathrm{OB}}$ and start their radial migration do this along blood vessels. In accordance with our results are observations showing close association of radially migrating cells in the OB with blood vessels (Bovetti et al., 2007).

BDNF and mechanisms of vasculature-associated migration of newborn cells

BDNF plays an important role in the neuronal migration during development (Polleux et al., 2002; Marín and Rubenstein, 2003; 
Zhou et al., 2007). Here, by modulating the level of BDNF expression specifically in the adults, we show that vasculature-derived BDNF controls neuronal migration in the adult SVZ-OB pathway. Interestingly, the effect of BDNF is directly mediated by p75NTR present on the neuroblast. Several studies have examined the expression pattern of p75NTR in the SVZ and RMS of adult and young animals [postnatal day 7 (P7)] (Giuliani et al., 2004; Gascon et al., 2007; Young et al., 2007; Bath et al., 2008; Galvão et al., 2008). Although most of the p75NTR immunoreactivity in the adult SVZ was associated with a small fraction of proliferating nestin ${ }^{+}$cells (Giuliani et al., 2004; Young et al., 2007), some of the migrating neuronal precursors have been also shown to express p75NTR (Young et al., 2007; Galvão et al., 2008). p75NTR is not observed in the RMS of young animals (P7) (Gascon et al., 2007), but, when neuronal precursors are cultured in vitro, they start to express high levels of this neurotrophic receptor (Gascon et al., 2005). Recently, it has been reported that, in the adult RMS, p75NTR is present on rapidly dividing C-type cells (Bath et al., 2008). This population of cells is, however, essentially undetectable in electron microscopic studies of the adult RMS (Doetsch et al., 1997; Gritti et al., 2002). Another study that has examined expression of p75NTR in the adult RMS has reported the presence of "immunoreactive cells assembled in the continuous chains and elongated in the direction parallel to the migratory stream" (Giuliani et al., 2004), consistent with the data reported here. Using immunolabeling with cell-type-specific markers, semiquantitative RT-PCR of FACS-purified neuroblasts and astrocytes, function-blocking antibodies for p75NTR, genetically engineered mice deficient for this receptor, and timelapse video microscopy of cell migration, we demonstrated that p75NTR is expressed by migrating neuroblasts in the adult RMS and controls their migration in response to BDNF. It has been shown previously that p75NTR is involved in axonal growth, as well as the migration of glioma and Schwann cells (Anton et al., 1994; Johnston et al., 2007). Intriguingly, 28 d after BrdU injection, no differences in the number of $\mathrm{BrdU}^{+}$cells was detected in the OB of p75NTR-deficient animals (Bath et al., 2008). These data suggest that different survival rates of newly arrived neurons in the OB of p75NTR-deficient mice compared with wild-type littermates might be involved. Together with recently published data implicating this receptor in the neuroblasts production (Young et al., 2007), our data indicate that p75NTR plays a dual role in the adult $\mathrm{OB}$ neurogenesis by controlling the generation of neuronal precursors (Young et al., 2007) and their migration toward and into OB.

Our data also suggest that the migrating neuroblasts themselves might regulate the level of extracellular BDNF and, therefore, the duration of their migratory phase. GABA released from migrating neuroblasts induces $\mathrm{Ca}^{2+}$ fluctuations in astrocytes through activation of $\mathrm{GABA}_{\mathrm{A}}$ receptors. This $\mathrm{Ca}^{2+}$ activity led to the insertion of high-affinity TrkB receptors on the plasma membrane of astrocytes and subsequently to the trapping of extracellular BDNF. We hypothesize that, through this mechanism, neuroblasts can control the periodicity of their migratory and stationary phases. Thus, the astrocytes that ensheath neuronal precursors (Alvarez-Buylla and Garcia-Verdugo, 2002; Lledo and Saghatelyan, 2005) and contact blood vessels play an important regulatory role in the vasculature-associated migration of neuronal precursors, because they regulate the amount of free BDNF available to migrating neuronal precursors. Our data, therefore, reveal a novel mechanism by which astrocytes regulate neuronal migration in the adult RMS. In agreement with this are our results showing that conditional removal of TrkB receptors on as- trocytes drastically affects neuronal migration in the adult brain. It is conceivable that neuronal precursors undergo stationary periods to accumulate energy and receive additional signals for their migration. We hypothesize that removing this important regulatory cascade that ensures periodicity of migratory and stationary phases leads to the abnormal migration of neuronal precursors and, therefore, to reduced number of BrdU ${ }^{+}$cells in the OB $5 \mathrm{~d}$ after BrdU injection. Our data are in line with recently reported reduction in the number of $\mathrm{BrdU}^{+}$cells, $28 \mathrm{~d}$ after BrdU injection, in TrkB haploinsufficient mice (Bath et al., 2008). This effect was, however, attributed to the role of TrkB receptors expressed on neuroblasts (Chiaramello et al., 2007; Bath et al., 2008). Here, using acute slices prepared from the adult forebrain, we were not able to detect any effect of TrkB inhibitor on neuronal migration. In addition, application of BDNF or TrkB-Fc in the slices prepared from p75NTR-deficient mice and direct real-time monitoring of cell migration did not reveal any differences in the migratory behavior of neuroblasts. These results are in line with the recently proposed role for TrkB receptors in the adult SVZ-RMS pathway (Galvão et al., 2008). Together, the mechanisms described here offer a simple and cogent explanation of long-range migration of neuronal precursors in the adult brain.

\section{References}

Alderson RF, Curtis R, Alterman AL, Lindsay RM, DiStefano PS (2000) Truncated TrkB mediates the endocytosis and release of BDNF and neurotrophin-4/5 by rat astrocytes and schwann cells in vitro. Brain Res $871: 210-222$.

Altman J, Das GD (1966) Autoradiographic and histological studies of postnatal neurogenesis. I. A longitudinal investigation of the kinetics, migration and transformation of cells incorporating tritiated thymidine in neonate rats, with special reference to postnatal neurogenesis in some brain regions. J Comp Neurol 126:337-389.

Alvarez-Buylla A, Garcia-Verdugo JM (2002) Neurogenesis in adult subventricular zone. J Neurosci 22:629-634.

Anton ES, Weskamp G, Reichardt LF, Matthew WD (1994) Nerve growth factor and its low-affinity receptor promote Schwann cell migration. Proc Natl Acad Sci U S A 91:2795-2799.

Anton ES, Ghashghaei HT, Weber JL, McCann C, Fischer TM, Cheung ID, Gassmann M, Messing A, Klein R, Schwab MH, Lloyd KC, Lai C (2004) Receptor tyrosine kinase ErbB4 modulates neuroblast migration and placement in the adult forebrain. Nat Neurosci 7:1319-1328.

Bath KG, Mandairon N, Jing D, Rajagopal R, Kapoor R, Chen ZY, Khan T, Proenca CC, Kraemer R, Cleland TA, Hempstead BL, Chao MV, Lee FS (2008) Variant brain-derived neurotrophic factor (Val66Met) alters adult olfactory bulb neurogenesis and spontaneous olfactory discrimination. J Neurosci 28:2383-2393.

Bédard A, Parent A (2004) Evidence of newly generated neurons in the human olfactory bulb. Brain Res Dev Brain Res 151:159-168.

Belvindrah R, Hankel S, Walker J, Patton BL, Müller U (2007) Betal integrins control the formation of cell chains in the adult rostral migratory stream. J Neurosci 27:2704-2717.

Benraiss A, Chmielnicki E, Lerner K, Roh D, Goldman SA (2001) Adenoviral brain-derived neurotrophic factor induces both neostriatal and olfactory neuronal recruitment from endogenous progenitor cells in the adult forebrain. J Neurosci 21:6718-6731.

Berthod F, Germain L, Tremblay N, Auger FA (2006) Extracellular matrix deposition by fibroblasts is necessary to promote capillary-like tube formation in vitro. J Cell Physiol 207:491-498.

Bolteus AJ, Bordey A (2004) GABA release and uptake regulate neuronal precursor migration in the postnatal subventricular zone. J Neurosci 24:7623-7631.

Bovetti S, Hsieh YC, Bovolin P, Perroteau I, Kazunori T, Puche AC (2007) Blood vessels form a scaffold for neuroblast migration in the adult olfactory bulb. J Neurosci 27:5976-5980.

Chiaramello S, Dalmasso G, Bezin L, Marcel D, Jourdan F, Peretto P, Fasolo A, De Marchis S (2007) BDNF/TrkB interaction regulates migration of SVZ precursor cells via PI3-K and MAP-K signalling pathways. Eur J Neurosci 26:1780-1790. 
Clary DO, Reichardt LF (1994) An alternatively spliced form of the nerve growth factor receptor TrkA confers an enhanced response to neurotrophin 3. Proc Natl Acad Sci U S A 91:11133-11137.

Conover JC, Doetsch F, Garcia-Verdugo JM, Gale NW, Yancopoulos GD, Alvarez-Buylla A (2000) Disruption of Eph/ephrin signaling affects migration and proliferation in the adult subventricular zone. Nat Neurosci 3:1091-1097.

Cremer H, Lange R, Christoph A, Plomann M, Vopper G, Roes J, Brown R, Baldwin S, Kraemer P, Scheff S, Barthels D, Rajewsky K, Wille W (1994) Inactivation of the $\mathrm{N}-\mathrm{CAM}$ gene in mice results in size reduction of the olfactory bulb and deficits in spatial learning. Nature 367:455-459.

Doetsch F, García-Verdugo JM, Alvarez-Buylla A (1997) Cellular composition and three-dimensional organization of the subventricular germinal zone in the adult mammalian brain. J Neurosci 17:5046-5061.

Du J, Feng L, Zaitsev E, Je HS, Liu XW, Lu B (2003) Regulation of TrkB receptor tyrosine kinase and its internalization by neuronal activity and $\mathrm{Ca}^{2+}$ influx. J Cell Biol 163:385-395.

Fraser DD, Duffy S, Angelides KJ, Perez-Velazquez JL, Kettenmann H, MacVicar BA (1995) $\mathrm{GABA}_{\mathrm{A}} /$ benzodiazepine receptors in acutely isolated hippocampal astrocytes. J Neurosci 15:2720-2732.

Galvão RP, Garcia-Verdugo JM, Alvarez-Buylla A (2008) Brain-derived neurotrophic factor signaling does not stimulate subventricular zone neurogenesis in adult mice and rats. J Neurosci 28:13368-13383.

Gascon E, Vutskits L, Zhang H, Barral-Moran MJ, Kiss PJ, Mas C, Kiss JZ (2005) Sequential activation of p75 and TrkB is involved in dendritic development of subventricular zone-derived neuronal progenitors in vitro. Eur J Neurosci 21:69-80.

Gascon E, Vutskits L, Jenny B, Durbec P, Kiss JZ (2007) PSA-NCAM in postnatally generated immature neurons of the olfactory bulb: a crucial role in regulating p75 expression and cell survival. Development 134:1181-1190.

Giuliani A, D’Intino G, Paradisi M, Giardino L, Calzà L (2004) p75(NTR)immunoreactivity in the subventricular zone of adult male rats: expression by cycling cells. J Mol Histol 35:749-758.

Goggi J, Pullar IA, Carney SL, Bradford HF (2003) The control of [125I]BDNF release from striatal rat brain slices. Brain Res 967:201-209.

Gritti A, Bonfanti L, Doetsch F, Caille I, Alvarez-Buylla A, Lim DA, Galli R, Verdugo JM, Herrera DG, Vescovi AL (2002) Multipotent neural stem cells reside into the rostral extension and olfactory bulb of adult rodents. J Neurosci 22:437-445.

Guo S, Kim WJ, Lok J, Lee SR, Besancon E, Luo BH, Stins MF, Wang X, Dedhar S, Lo EH (2008) Neuroprotection via matrix-trophic coupling between cerebral endothelial cells and neurons. Proc Natl Acad Sci U S A 105:7582-7587.

Hack I, Bancila M, Loulier K, Carroll P, Cremer H (2002) Reelin is a detachment signal in tangential chain-migration during postnatal neurogenesis. Nat Neurosci 5:939-945.

Hinds JW (1968) Autoradiographic study of histogenesis in the mouse olfactory bulb. II. Cell proliferation and migration. J Comp Neurol 134:305-322.

Hu H, Tomasiewicz H, Magnuson T, Rutishauser U (1996) The role of polysialic acid in migration of olfactory bulb interneuron precursors in the subventricular zone. Neuron 16:735-743.

Jankovski A, Sotelo C (1996) Subventricular zone-olfactory bulb migratory pathway in the adult mouse: cellular composition and specificity as determined by heterochronic and heterotopic transplantation. J Comp Neurol 371:376-396.

Jankovski A, Garcia C, Soriano E, Sotelo C (1998) Proliferation, migration and differentiation of neuronal progenitor cells in the adult mouse subventricular zone surgically separated from its olfactory bulb. Eur J Neurosci 10:3853-3868.

Johnston AL, Lun X, Rahn JJ, Liacini A, Wang L, Hamilton MG, Parney IF, Hempstead BL, Robbins SM, Forsyth PA, Senger DL (2007) The p75 neurotrophin receptor is a central regulator of glioma invasion. PLoS Biol 5:e212.

Kirschenbaum B, Doetsch F, Lois C, Alvarez-Buylla A (1999) Adult subventricular zone neuronal precursors continue to proliferate and migrate in the absence of the olfactory bulb. J Neurosci 19:2171-2180.

Lee KF, Li E, Huber LJ, Landis SC, Sharpe AH, Chao MV, Jaenisch R (1992) Targeted mutation of the gene encoding the low affinity NGF receptor p75 leads to deficits in the peripheral sensory nervous system. Cell 69:737-749.

Leventhal C, Rafii S, Rafii D, Shahar A, Goldman SA (1999) Endothelial trophic support of neuronal production and recruitment from the adult mammalian subependyma. Mol Cell Neurosci 13:450-464.

Liu X, Wang Q, Haydar TF, Bordey A (2005) Nonsynaptic GABA signaling in postnatal subventricular zone controls proliferation of GFAPexpressing progenitors. Nat Neurosci 8:1179-1187.

Lledo PM, Saghatelyan A (2005) Integrating new neurons into the adult olfactory bulb: joining the network, life-death decisions, and the effects of sensory experience. Trends Neurosci 28:248-254.

Lois C, García-Verdugo JM, Alvarez-Buylla A (1996) Chain migration of neuronal precursors. Science 271:978-981.

Louissaint A Jr, Rao S, Leventhal C, Goldman SA (2002) Coordinated interaction of neurogenesis and angiogenesis in the adult songbird brain. Neuron 34:945-960.

Marín O, Rubenstein JL (2003) Cell migration in the forebrain. Annu Rev Neurosci 26:441-483.

Mason HA, Ito S, Corfas G (2001) Extracellular signals that regulate the tangential migration of olfactory bulb neuronal precursors: inducers, inhibitors, and repellents. J Neurosci 21:7654-7663.

Minichiello L, Korte M, Wolfer D, Kühn R, Unsicker K, Cestari V, RossiArnaud C, Lipp HP, Bonhoeffer T, Klein R (1999) Essential role for TrkB receptors in hippocampus-mediated learning. Neuron 24:401-414.

Mori T, Tanaka K, Buffo A, Wurst W, Kühn R, Götz M (2006) Inducible gene deletion in astroglia and radial glia-a valuable tool for functional and lineage analysis. Glia 54:21-34.

Murase S, Horwitz AF (2002) Deleted in colorectal carcinoma and differentially expressed integrins mediate the directional migration of neural precursors in the rostral migratory stream. J Neurosci 22:3568-3579.

Ng KL, Li JD, Cheng MY, Leslie FM, Lee AG, Zhou QY (2005) Dependence of olfactory bulb neurogenesis on prokineticin 2 signaling. Science 308:1923-1927.

Ono K, Tomasiewicz H, Magnuson T, Rutishauser U (1994) N-CAM mutation inhibits tangential neuronal migration and is phenocopied by enzymatic removal of polysialic acid. Neuron 13:595-609.

Ono M, Yanagawa Y, Koyano K (2005) GABAergic neurons in inferior colliculus of the GAD67-GFP knock-in mouse: electrophysiological and morphological properties. Neurosci Res 51:475-492.

Paratcha G, Ibáñez CF, Ledda F (2006) GDNF is a chemoattractant factor for neuronal precursor cells in the rostral migratory stream. Mol Cell Neurosci 31:505-514.

Pencea V, Bingaman KD, Wiegand SJ, Luskin MB (2001) Infusion of brainderived neurotrophic factor into the lateral ventricle of the adult rat leads to new neurons in the parenchyma of the striatum, septum, thalamus, and hypothalamus. J Neurosci 21:6706-6717.

Polleux F, Whitford KL, Dijkhuizen PA, Vitalis T, Ghosh A (2002) Control of cortical interneuron migration by neurotrophins and PI3-kinase signaling. Development 129:3147-3160.

Rubio N (1997) Mouse astrocytes store and deliver brain-derived neurotrophic factor using the non-catalytic gp95trkB receptor. Eur J Neurosci 9:1847-1853.

Saghatelyan A, de Chevigny A, Schachner M, Lledo PM (2004) Tenascin-R mediates activity-dependent recruitment of neuroblasts in the adult mouse forebrain. Nat Neurosci 7:347-356.

Sawamoto K, Wichterle H, Gonzalez-Perez O, Cholfin JA, Yamada M, Spassky N, Murcia NS, Garcia-Verdugo JM, Marin O, Rubenstein JL, Tessier-Lavigne M, Okano H, Alvarez-Buylla A (2006) New neurons follow the flow of cerebrospinal fluid in the adult brain. Science 311:629-632.

Wu W, Wong K, Chen J, Jiang Z, Dupuis S, Wu JY, Rao Y (1999) Directional guidance of neuronal migration in the olfactory system by the protein Slit. Nature 400:331-336.

Young KM, Merson TD, Sotthibundhu A, Coulson EJ, Bartlett PF (2007) p75 neurotrophin receptor expression defines a population of BDNFresponsive neurogenic precursor cells. J Neurosci 27:5146-5155.

Zhou P, Porcionatto M, Pilapil M, Chen Y, Choi Y, Tolias KF, BikoffJB, Hong EJ, Greenberg ME, Segal RA (2007) Polarized signaling endosomes coordinate BDNF-induced chemotaxis of cerebellar precursors. Neuron 55: $53-68$. 